\title{
100.Yılında Uluslararası Çalışma Örgütü: Değişen Koşullarda Politika Tercihleri ve Yönelimler
}

\section{The ILO at Centenary: Political Preferences and Tendencies in Changing Conditions}

Özlem Özgür Büyükdere ${ }^{1}$ (1)

\begin{abstract}
Öz
Makalede Uluslararası Çalışma Örgütü’nün (UÇÖ), kuruluşundan bu yana dünyayı derinden etkileyen ekonomik, sosyal ve siyasal değişimlere, ortaya çıkan problemler ile çalışma hayatına yönelik beklentilere hangi politika ve faaliyetlerle karşııı verdiği incelenmiştir. Araştırmada literatür taraması ile elde edilen veriler kullanılmıştır. Çalışmada ilk olarak evrensel barış için sosyal adalet arayışına dayanan UçÖ’nün kuruluş süreci dünya savaşları penceresinden ele alınmıştır. Ardından refah devleti dönemi ve sonrasında neoliberal politikaların önderliğinde şekillenen küreselleşme sürecinde UçÖ’nün izlediği politikalar incelenmiştir. Son olarak, milenyum ile birlikte yeniden yapılanma sürecine giren UÇÖ’nün, dünya ölçeğinde çalışma ve yaşam koşullarının iyileştirilmesi misyonunu gerçekleştirmek için belirlediği yeni yol haritası üzerinde durulmuş ve yakın gelecekte izlenmesi gereken politikalar konusundaki önerilere yer verilmiştir. Çalışmada elde edilen sonuçlar UÇö’nün, bir asırdır toplumsal yapılar ve değişmeler ile uluslararası konjonktürleri dikkate alarak politikalar oluşturduğunu ortaya koymaktadır. Bu tutumunu 21. yüzyılda da devam ettiren UÇÖ, küreselleşmenin yapılandırıması sürecinde çalışma hayat ile ilgili standart oluşturma amacıyla proaktif politikalar takip etmektedir. Bu gelişmeler günümüzde olduğu gibi gelecekte de UçÖ’nün çalışma hayat ve uluslararası ekonomik ilişkilerdeki önem ve etkinliğinin artacağını göstermektedir.
\end{abstract}

\section{Anahtar Kelimeler}

Uluslararası Çalışma Örgütü, Sosyal adalet, Uygun iş, Küreselleşme, İşin geleceği

\begin{abstract}
The paper presents the International Labour Organization (ILO), which has addressed economic, social, and political changes, through its policies and activities and has examined emerging problems and expectations for working life. The current research is based on a literature review. The establishment of the

1 Sorumlu Yazar: Özlem Özgür Büyükdere (Doktora Öğrencisi), İstanbul Üniversitesi, Sosyal Bilimler Enstitüsü, Çalışma Ekonomisi ve Endüstri İlişkileri Bölümü, İstanbul, Türkiye. E-posta: O.Buyukdere@ticaret.gov.tr ORCID: 0000-0003-2600-1274
\end{abstract}

Atıf: Buyukdere, O. O. (2019). 100.yılında uluslararası çalışma örgütü: Değişen koşullarda politika tercihleri ve yönelimler. Sosyal Siyaset Konferansları Dergisi, 77: 59-96. https://doi.org/10.26650/jspc.2019.77.0015 
ILO is first discussed from the World War perspective, that is, based on seeking universal peace for social justice. Then, the ILO's policies, which were adopted during the welfare state period and globalization age and shaped under the leadership of neoliberal policies, are examined. Lastly, the ILO's new road map, which aims to accomplish its mission to improve global working and living conditions, is emphasized and policy suggestions are presented for future studies. Results show that the ILO established its policies by considering social structures and changes and international conjunctures for a century. Continuing this approach in the 21st century, the ILO pursues proactive policies with the aim of setting standards for working life in the structuring period of globalization. These developments demonstrate that the ILO's current importance and effectiveness for working life and international economic relations will increase in the future.

\section{Keywords}

International Labour Organization, Social Justice, Decent Work, Globalization, Future of Work 


\section{Extended Summary}

The International Labour Organization (ILO) was founded in 1919 because of the urgent need to improve the terrible working conditions during the Industrial Revolution. Its constitution was a response to inhumane working conditions. According to the ILO, universal and lasting peace can be established only if it is based on social justice. To date, two political arguments of this philosophy remain valid, namely, inhumane working conditions threaten universal and lasting peace and the failure of any country to adopt humane working conditions is an obstacle for other nations aiming to improve their conditions.

During the initial decades, economic recession and the balance between the market and state enabled the ILO to extend its standard setting activities. The ILO adopted several conventions and recommendations concerning unemployment and working hours, enlarged its research capacity, and collected statistical data. Later, in light of the World War II, The Declaration of Philadelphia was adopted in 1944. According to the declaration, which was a strong call for international cooperation for social progress, labor should not be regarded as a commodity.

In the 1950s and 1960s, after the World War II, the conjunctural expansion period and political climate helped the ILO's values to become widespread. However, the Cold War restricted the organization's sphere of action. After the decolonization movement, the ILO launched technical cooperation programs, such as the World Employment Programme. Conversely, the influence of technological and demographical changes on employment and production processes transformed the work force. However, such changes weakened the traditional labor movement. The ILO's agenda included new skills for new jobs. In this period, the number of fundamental conventions of the organization increased to five.

In the 1980s, economic recession and neoliberal policies, such as privatization and labor market deregulation, restricted the ILO's room to maneuver. In this period, the number of informal and precarious jobs considerably grew, and tripartism was substantially criticized. Multinationals expanded their power, and the number and intensity of crises increased because of the dominance of economic liberalization and financial markets. The social costs of such crises necessitated urgent social action; however, the constituents of the organization failed to reach a unified reaction, and standard setting facilities were delayed. 
Then, the ILO took its first step toward building a social floor to globalization and adopted a universal instrument, namely, the ILO Declaration on Fundamental Principles and Rights at Work and its follow-up in 1998.

The 2000s came with broadening inequalities. As a response, the ILO shaped its new road map and adopted the Decent Work Agenda as the main instrument to support the social dimension of globalization. The concept of decent work returned to an official document within the ILO in 2008. The ILO Declaration on Social Justice for a Fair Globalization brought together four strategic objectives, namely, rights at work, employment, social protection, and social dialogue and became the framework of the ILO's primary goal. As a response to the Financial Crisis of 2008, the ILO adopted the Global Jobs Pact and took part in the Social Protection Floor Initiative.

Then, the ILO deepened its cooperation with G20, which received a central position in the global governance system after 2008 and increased its recognition in the multilateral system. The Decent Work Agenda, Global Jobs Pact, and Millennium Development Goals later became references to G20 policies. Since then, the ILO has continued its efforts to deepen cooperation and dialogue with other international organizations as part of its reform policy. To date, apart from cooperating with international organizations, the ILO takes part in joint projects with several non-governmental organizations and provides technical assistance.

The world of work is transformatively changing and uncertainty emerges about the capacity of existing institutions and policies to provide the future that all people desire. Aware of such transformative changes, the ILO adopted the ILO Centenary Declaration in 2019 as an integrated policy response. At the same time, it serves as a guide for social justice and lasting peace. In the declaration, the importance of work for human welfare and spiritual and material well-being is underlined, and the need for acting urgently to seize the opportunities and address the challenges using human-centered approaches is emphasized. Promoting decent work and international labor standards, strengthening the capacity of its tripartite constituents, and playing an important role in the multilateral system are the main goals of the ILO in its second century.

In today's era of instant flow of information and communication, the timeliness of the ILO's responses to extreme changes in the industrial and occupational 
structures will determine its effectiveness in the global governance system in the future. The application of information and communication technologies, green economy, and demographic changes will create new jobs. However, mass crowds who lack future capabilities will lose their jobs. Poverty, inequalities, and labor market problems continue despite economic growth. Evidence from recent years shows that Sustainable Development Goal 8 is unlikely to be achieved until 2030. Social partners are looking for a universal labor guarantee system, social dialogues that include rural and informal economies, and international cooperation. The ILO can strengthen social dialogue by balancing power relations between employers and workers and actively taking part in corporate social responsibility initiatives. Thus, the need for the ILO to build a universal framework for fair globalization is becoming increasingly important. 


\section{Yılında Uluslararası Çalışma Örgütü: Değișen Koşularda Politika Tercihleri ve Yönelimler}

Uluslararası Çalışma Örgütü’nün (UÇÖ), “evrensel barış için sosyal adalet” amacını gerçekleştirmek üzere kuruluşunun üzerinden bir asırlık süre geçmiştir. $\mathrm{Bu}$ zaman zarfında meydana gelen ekonomik ve sosyal değişimler, savaşlar ve küreselleşme süreci gibi gelişmeler karşısında UÇÖ; devlet ve piyasa, toplum ve birey, ekonomik, sosyal ve çevresel politikalarla sürdürülebilir kalkınma arasında dengeli yaklaşımlara sahip politikalar geliştirmiştir. UÇÖ bu yaklaşımı ile çalışma hayatına ilişkin yerel ve küresel seviyede karar vericilerin dikkate almak durumunda kaldıkları, vazgeçilmez bir kurum niteliği kazanmıştır.

Y1llar içerisinde UÇÖ’nün etkinliği devlet ve piyasa dengesinde devletin konumuna ve ekonomik konjonktüre bağlı olarak değişirken, çalışan kesim ve toplumun geneli bakımından önemli kazanımlar elde edilmiştir. Bu kazanımların elde edilmesinde UÇÖ’nün dünyadaki özellikle siyasal ve makroekonomik değişimleri dikkate alarak, gelişmelere verdiği yerinde tepkilerin etkili olduğu kuşkusuzdur. UÇÖ’nün sözleşme ve tavsiye kararlarının gerek oluşum gerekse üye ülkelerce kabulü ve uygulanması süreçlerinde uygun teknikler geliştirmesi önemli rol oynamıştır. Üye ülkelerin heyetlerinin sosyal tarafları içeren üçlü temsili de UÇÖ’nün etkinliği üzerinde olduğu kadar sürekliliği ve kökleşmesi üzerinde belirleyici olmuştur. Bununla birlikte, dünya genelinde işsizlik, enformel istihdam, yoksulluk, sosyal güvenlik, eşitsizlik, sosyal diyalog, örgütlenme, toplu pazarlık ve çalışma hayatını ilgilendiren diğer alanlarda çözüm bekleyen pek çok problem de var olmaya devam etmektedir. Bu durum, hem UÇÖ’nün kuruluşunda kabul ettiği sosyal adalet ve evrensel barış misyonunun güncelliğini koruduğuna, hem de küreselleşmenin derinleşmesiyle mevcut olanların yanı sıra ortaya çıkan yeni sorunların üstesinden gelinmesinde ve ülkelerin ekonomik ve sosyal değişim süreçlerinin yapılandırılmasında, UÇÖ’nün öneminin ve etkinliğinin artacağına işaret etmektedir.

Bu çerçevede, çalışmada UÇÖ’nün yukarıda bahsedilen değişimlere ve ortaya çıkan problemler ile çalışma hayatına yönelik beklentilere hangi politika ve faaliyetlerle karşılık verdiği, tarihsel olarak üç başlık altında, literatür taraması sonucunda elde olunan veriler kapsamında incelenmektedir. Önce evrensel barış için sosyal adalet arayışına dayanan UÇÖ’nün kuruluş süreci dünya savaşları penceresinden değerlendirilmiştir. Ardından refah devleti dönemi ve sonrasında neoliberal küreselleşme dönemine denk gelen UÇÖ’nün kurumsal 
gelişme sürecinde izlediği politikalar incelenmiştir. Sonrasında milenyum ile birlikte yeniden yapılanma sürecine giren UÇÖ’nün, dünya ölçeğinde çalışma ve yaşam koşullarının iyileştirilmesi misyonunu gerçekleştirmek için belirlenen yeni yol haritası üzerinde durulmuş ve yakın gelecekte izlenmesi gereken politikalar konusundaki önerilerle çalışma sonlandırılmıştır.

\section{UÇÖ: Evrensel Barış İçin Sosyal Adalet Arayışı}

\section{Birinci Dünya Savaşı: Paris Barış Konferansı}

UÇÖ, dünya tarihinde yaşanan en büyük dönüşümlerden birinin sonucunda kurulmuştur. Geçmişteki eğilimler değerlendirilirken günümüzde yaşanan ekonomik dönüşüm ve sınırların yok oluşunun daha önce bu boyut ve hıda yaşanmadığı dile getirilse de Sanayi Devrimi sürecinde bu gelişmelerin öncülerine rastlanmış, dışa açık bir ekonominin getirileri bugünküne benzer umutlar yeşertirken, 1820 sonrasında ulaşım ve iletişim maliyetlerinin azalmasıyla, uluslararası ticaret ciddi bir ivme kazanmıştır. Dünya toplam yıllık gelir artış1 \%2,1'in üzerine çıkarken, ihracat artışları \%3,4'ü bulmuş; ticari açıklık olarak ifade edilen ticaretin toplam gelir içindeki payı, 1. Dünya Savaşı'nın hemen öncesinde ulaştı̆̆ zirveye 1960'lara kadar tekrar ulaşamamıştır (World Trade Organization, 2013, s. 47). Diğer yandan, ticaret ve teknolojik yeniliklerin oluşturacağı kombinasyonun yeni bir refah dönemi yaratarak çalışma koşullarını iyileştireceği müjdelenmiştir. Ancak Sanayi Devrimi; kitlesel göçler, işgücü piyasasını ve toplumu yüzyıllar boyunca idare eden geleneksel kuralların yok olması ve birçok sosyal sorunla birlikte, "geniş kitlelerin istismarını, güvencesizliğini ve 1stırabını” da beraberinde getirmiştir (Thompson, 1966, s. 212).

Bu bağlamda UÇÖ’nün kuruluş süreci; Sanayi Devrimi'nin özellikle ilk yıllarında işçilerin; sağlıksız ortamlarda, uzun saatler boyunca, kontrol edilmemiş ve tehlikeli materyallerle, aileleriyle birlikte ancak çok olumsuz şartlarda yaşamalarına yetecek düzeyde ücretlerle çalışmak zorunda bırakılmalarına ve bu olumsuz çalışma koşullarının acil olarak iyileştirilmesi ihtiyacına uzanmaktadır (Rodgers vd., 2009, s. 93). Günümüzde geçerliliğini koruyan en önemli küresel sosyal sözleşme niteliğindeki UÇÖ Anayasası (ILO, 2019a, s. 23) girişte tam da bu noktaya değinmekte; çalışma koşullarının; çalışma süresinin sınırlanması, işgücü arzının düzenlenmesi, işsizliğin önlenmesi, insanca yaşamaya yetecek 
ücretlendirme sisteminin oluşturulması, çalışanların genel ve meslek hastalıkları ile iş kazalarına karşı korunması, dezavantajlı grupların gözetilmesi, yaşlılık ve maluliyet aylıklarının bağlanması, ücret eşitliği ve sendikal özgürlük ilkesinin sağlanması, teknik ve mesleki eğitimin düzenlenmesi gibi önlemlerle iyileştirilmesi çağrısında bulunmaktadır (ILO, 1919).

Sanayi Devrimi'yle ortaya çıkan olumsuz çalışma koşullarının toplumsal barış ve ekonomik istikrarı tehdit etmesi dönemin bazı politikacılarının yanı sıra Robert Owen, Daniel Legrand gibi işverenleri de harekete geçirmiş; çalışma standartlarının, uluslararası düzlemde kabul görecek şekilde, her ülke için asgari ölçüde düzenlenmesi gündeme gelmiştir (Morse, 1969, s. 6). Bu kişiler, organize olarak korunmadığı sürece, uluslararası çalışma haklarının; liberal politikalarla uluslararası ticari rekabetten olumsuz etkileneceği inancındaydılar. İşçi kesimi ise 19. Yüzyıl'ın ikinci yarısında çok sayıda örgüt oluşturarak konferanslar tertip etmiş, işçilerin refahını artıracak ve gelir dağılımını iyileştirecek uluslararası düzenlemeler lehine görüş bildirmiştir. Bu bilinçlenme ilk meyvesini Paris Barış Konferansı'nda vermiş, oluşturulan çalışma komisyonunda delegelerin çoğu 1918-1919 yıllarında özellikle Avrupa'daki çalışma hayatı ve endüstri ilişkilerinin istikrarsız yapısının, acil ve yapıcı müdahaleyi gerektirdiği üzerinde hemfikir olmuşlardır (Morse, 1969, s. 4). Böylece, var olan çalışma şartlarını dünyanın politik, sosyal ve ekonomik istikrarına katkı sağlama amacıyla iyileştirme fikri, 1. Dünya Savaşı sonrasında gerçekleştirilen barış görüşmelerinin gündemine dâhil olmuş ve bu amaçla toplanan komisyon 1 Şubat-4 Mart 1919 tarihleri arasında çalışmalarda bulunmuştur (Perez, 2013, s. 114). Paris Barış Konferansı'nın çok önemli bir diğer katkısı da kapsayıcı ve bütüncül bir kalkınma görüşünün öncül ifadesi olan (Langille, 2003-2004, s. 87-99) UÇÖ Anayasası'nın taslağının hazırlanmış olmasıdır. Böylece, 20. Yüzyıl'ın başlarında, dünyanın karşı karşıya olduğu ekonomik ve sosyal sorunların üzerine eğilecek uluslararası örgütler oluşturmaya yönelik ilk adım atılmıştır (Rodgers vd., 2009, s. 6).

UÇÖ, Haziran 1919'da 1. Dünya Savaşı'nın sona erdiren Versay Anlaşması'nın bir parçası olarak kurulduğunda, evrensel barışın sadece sosyal adalet temelinde yükselebileceği fikri üzerinde temellenmiş; örgütün kurucuları, insanca çalışma koşullarını dünyanın her tarafına yaymak, eşitsizliklerle ve yoksullukla mücadele etmek hedefiyle yola çıkmışlardır (ILO, 12 February 2008, s.2). Yine UÇÖ Anayasası'nın girişinde iki temel politik argümana yer verilerek çalışma koşullarının iyileştirilememesi halinde dünya barış ve huzurunun tehlikeye 
gireceği, çalışma koşullarını insanileştirmeyen bir ülkenin, kendi ülkelerindeki çalışma koşullarını iyileştirmek isteyen diğer ülkelerin önünde engel olarak duracağı vurgulanmıştır. Anayasa'nın girişinde sosyal adaleti sağlamak üzere işsizliğin önlenmesi ile insanca yaşamaya yetecek bir ücretlendirme politikasının oluşturulmasına yönelik önlemlere doğrudan atıf yapılmak suretiyle (ILO, 1919) UÇÖ’nün ulusal ve uluslararası ekonomi politikalarını etkileme potansiyeline sahip olması amaçlanmıştır. Kurucular bu hedeflere; işçi ve işveren kesimleri ile devletin oluşturacağı üçlü yapının yaratacağı sosyal diyalog atmosferinde uluslararası çalışma standartlarının inşasıyla ulaşmak niyetindeydiler (Gravel, Kohiyama ve Tsotroudi, 2014, s. 1).

Birinci Dünya Savaşı sonrasında, sanayileşmiş ülkelerdeki yüksek enflasyon gibi sorunlarla yüzleşme gereği, UÇÖ’nün faaliyetlerine başladığı döneme denk gelmiş; UÇÖ’nün günlük ve haftalık çalışma sürelerine sınır getiren ve işsizlikle mücadeleyi hedefleyen 1 ve 2 sayılı sözleşmeleri UÇÖ Genel Konferansı'nın ilk toplantısında kabul edilmiştir. Ardından ekonomik ve sosyal alanlar arasındaki etkileşimi gözler önüne serme niyetiyle UÇÖ’nün yetki alanı genişlemiş; 1930-1939 döneminde 39 sözleşme ve 32 tavsiye kararı alınmıştır. Yıllar sonra temel UÇÖ sözleşmeleri arasına girecek olan ve zorla çalıştırmayı yasaklayan 29 sayılı Sözleşme (1930), yine işsizlik sorununa yönelik ücretli istihdam büroları ile ilgili 34 sayılı Sözleşme (1933) ve işsizlik ödeneklerini düzenleyen 44 sayılı Sözleşme (1934) bu düzenlemeler arasında yer almıştır (Perez, 2013, s. 115-116).

UÇÖ’nün bu dönemdeki faaliyetleri, konjonktürel ortamın etkisiyle zenginleşmiştir. UÇÖ’nün kuruluş yıllarında devlet piyasa dengesi devletten tarafta bir görünüm sergilemiş; yaşanan istikrarsızlıklara rağmen ekonomik ve sosyal ilerlemeyi hedefleyen uluslararası bir kuruluş için ortam uygun seyretmiştir. Böylece UÇÖ; uluslararası standartların bir kısmını bu dönemde inşa edebilmiş; sosyal sigortalar, iş sağlı̆̆ ve güvenliği, iş kalitesi ile ilgili araştırma kapasitesini artırabilmiş, istatistiki bilgi toplayabilmiştir. Ancak 1930'ların başında atmosfer değişmiş; ekonomik krizin yayılması, ticaret ve finans sistemini korumacılığa kaydırmış; artan işsizlik demokrasileri yapısal bir krize sürüklemiştir. Roosevelt'in başkanlığında 1934'te UÇÖ’ye katılan ABD' de o dönemin, ekonomi yönetiminde Keynesçi görüşlerin hâkim olduğu, piyasanın kurallar dâhilinde düzenlendiği bir dönemi ifade etmesi; UÇÖ’nün istihdam meselesine uluslararası boyutta eğilmesini kolaylaştırıcı bir unsur olmuştur (Rodgers vd., 2009, s. 27-29). 


\section{İkinci Dünya Savaşı: Philadelphia Bildirgesi}

Büyük yıkımlara yol açan iki dünya savaşı, ara dönemdeki hiper enflasyon deneyimi ve altın standardının terk edilmesi; uluslararası finansal sistemi korumayı ve düzenlemeyi, ekonomik gelişmeyi teşvik etmeyi amaçlayan Uluslararası Para Fonu ve Dünya Bankası'nın kuruluşuyla sonuçlanmıştır (Igwe, 2018, s. 105-114). Bretton Woods kuruluşları olarak adlandırılan bu örgütlerin faaliyetiyle, ekonomik amaçlarla daha kapsamlı sosyal kaygılar arasında denge kurmayı hedefleyen UÇÖ’nün sorumlulukları artmıştır. Diğer yandan, İkinci Dünya Savaşı sonrasında yeni üyeler kazanan UÇÖ, gelişmekte olan ülkelere yönelik teknik yardımlarına ağırlık vermiştir (ILO, 12 February 2008, s.2).

İkinci Dünya Savaşı'nın bitimi öncesinde 1944'te Philadelphia'da kabul edilen bildirgeyle, belirlenen hedeflere ulaşmak için ulusal ve uluslararası boyutta işbirliğine ihtiyaç duyulduğu vurgulanmıştır. Daha önemlisi, UÇÖ’nün; üretim ve tüketimi artırmayı, finansal dalgalanmaları önlemeyi, yoksul ülkelerin sosyal ve ekonomik gelişimine destek olmayı, hammadde fiyatları ile uluslararası ticarette istikrarı kalıcı hale getirmeyi mümkün kılacak önlemleri almakta, diğer uluslararası kuruluşlarla sorumluluğu paylaşacağı ilan edilmiştir (ILO, 10 May 1944, s. 2-3). Bu bağlamda, Philadelphia Bildirgesi, evrensel bir sosyal gelişme için ulusal ve uluslararası eyleme duyulan ihtiyacın kuvvetli bir ifadesidir (Kunanayakam, 2013, s. 19). Bildirge ile ayrıca ekonomi politikalarının sosyal amaçlar doğrultusunda şekillendirilmesi talebinin temelini oluşturan, bireylerin evrensel sosyal haklara sahip olduğu fikri; uluslararası düzlemde dile getirilmeye başlanmıştır (Marshall ve Fenwick, 2016, s. 16).

Savaştan sonra oluşan bloklaşma ile yeni kurulan Bretton Woods Kuruluşları, UÇÖ’nün faaliyet alanını kısıtlamış; ancak İnsan Hakları Evrensel Bildirgesi'nin 1948'de kabulüyle öncelik insan haklarına verildiğinden, UÇÖ bu rüzgârın etkisiyle bir dizi sözleşmeyi hayata geçirmeyi başarmıştır. Philadelphia Bildirgesi'nde net amaçlara yer verilmesi Büyük Buhran ve 2. Dünya Savaşı sonrasında ekonomik ve sosyal politikalar arasındaki karşılıklı ilişkiyi güçlendirmiş, savaşın galiplerine yeni dünya düzenini şekillendireceğine inanılan ilke ve değerleri hayata geçirme firsatı sunmuş; böylece orijinal UÇÖ Anayasası ile geliştirilen vizyon bir adım ileriye taşınmıştır. Philadelphia Bildirgesi ile emeğin bir mal olmadığı, ifade ve örgütlenme özgürlüğünün sürdürülebilir gelişme için vazgeçilmez olduğu, bu ilkelerin ayrım gözetmeksizin tüm insanlar 
için geçerli olduğu, yoksulluğun nerede olursa olsun tehdit oluşturduğu ve yoksullukla mücadele için uluslararası işbirliğine ihtiyaç duyulduğu, sosyal adalet temeline dayanmayan barışın uzun ömürlü olamayacağı şeklinde özetlenebilecek temel UÇÖ ilkeleri doğrulanmakla kalmamış; UÇÖ’nün gelecekteki faaliyet alanı da şekillenmiştir. İnsan Hakları Evrensel Bildirgesi'ne paralel şekilde, sosyal adalet; özgürlükler ve insan haysiyetine bağlanmış ve ayrım gözetilmeksizin tüm insanların fiziksel, ruhsal ve ekonomik gelişmelerini sürdürme haklarının bulunduğuna ve bu nedenle de çalışanların korunması gerektiğine dikkat çekilmiştir (ILO, 10 May 1944, s. 1-2).

\section{Gelişme ve Küreselleşme Sürecinde UÇÖ}

\section{Refah Devleti Dönemi}

Dönemin 1950-1960'larda getirdiği politik iklim, gelişmiş ülkelerle birçok gelişmekte olan ülkedeki yüksek büyüme ve istihdam oranları, güçlü sendikal hareket, kurallı işgücü piyasaları, ABD ve Bretton Woods Kuruluşları'nın hegemonyası altında istikrarlı bir küresel ekonomi yönetimi; UÇÖ’nün değerlerinin yayılması için uygun bir ortam sağlamıştır. Bu dönemde UÇÖ’nün hareket kabiliyetini etkileyen ana faktörler; Soğuk Savaş, kolonilerin bağımsızlıklarını kazanması ile mesleki ve endüstriyel yapılardaki değişimler olmuştur. Bunlardan ilki kapsamında Soğuk Savaş döneminde, Sovyetler Birliği'nin 1954'te UÇÖ’ye yeniden katılımıyla alevlenen ideolojik tartışmalar, UÇÖ’nün küresel bir güç olarak hareket alanını kısıtlamış; örneğin Avrupa'nın bütünleşme sürecine sosyal boyutun da eklenmesi konusunda UÇÖ’nün oldukça pasif kalmasına yol açmıştır (Rodgers, vd., 2009, s. 30-31).

Kolonilerin bağımsızlıklarını kazanması ise, diğer yandan, UÇÖ’nün daha evrensel bir vizyonla dikkatleri az gelişmişlik, dış yardımlar ve dayanışma konularına çekebilmesine olanak sağlamıştır (Plata-Stenger, 2016). Bu dönemde eski koloni devletleri birçok UÇÖ sözleşmesine taraf olmuş, ancak bu devletler kalkınma sürecinde sosyal taraflardan işverenlerin yanında yer alarak sözleşmelerin uygulanması safhasında isteksiz davranmıştır. UÇÖ, gelişmekte olan ülkelerdeki bu farklı özellikteki ekonomik ve sosyal sorunlara, yeni bilgi, politika ve teknik yardım desteğiyle yaklaşarak, Küresel İstihdam Programı gibi işbirliği programları geliştirmiş; kalkınma, ayrımcılık gibi alanlardaki araştırmalara yoğunlaşmıştır (Kott, 2019, s. 31-34). 
Diğer yandan, mesleklerle ekonomik sektörlerin radikal dönüşümü; işin yapısını ve mekânsal boyutunu da ciddi oranda değiştirmiştir. İkinci Dünya Savaşı sonrasında üretimin küresel düzeyde yeniden yapılanması ve emekten tasarruf sağlayan teknolojilerin yaygınlaşmasıyla, gelişmişülkelerde ağır sanayi ve madencilik sektörlerindeki istihdam azalırken; tekstil, giyim ve ayakkabı başta olmak üzere birçok geleneksel sektör ile demir, çelik ve gemi inşaat sektörleri Brezilya, Güney Kore, Polonya, Romanya ve daha sonra Çin ve Hindistan gibi yeni sanayileşen ülkelere kaymış; sanayi sektöründeki işler yerini hizmetler sektöründeki işlere bırakmıştır. Yaşam 1920’lerde ağırlıklı olarak kırsalda sürerken, 2. Dünya Savaşı sonrası dönemden itibaren nüfusunun çoğunluğu kırsalda yaşayan ülkelerin sayısı hızla azalmış; sonrasında Sahra Altı Afrika ile Doğu ve Güney Doğu Asya'nın küçük bir bölgesine sıkışmıştır. Tarımın modernleşmesiyle çoğunlukla kadınlardan oluşan tarımsal istihdam şehirlere akmış, çalışan kesimin coğrafi dağılımı ve büyüklüğü değişmiş, UÇÖ’nün kuruluş yıllarında çalışma koşullarının iyileşmesi için birlikte sendikal mücadele veren çalışan kesim kaybolmamakla birlikte, yaşam koşulları ve ihtiyaçları itibariyle değişime uğramıştır. Hizmet sektörünün, beyaz yakalı kalifiye çalışan sayısının artışı; geleneksel işçi hareketini zayıflatmış, işlerin kalitesini ve güvencesini etkilemiştir. İşlerin gerektirdiği beceriler ve farklı gruplar arasındaki dağılımı ile ücretler ve verimlilik UÇÖ’nün gündemine dâhil olmuştur (Rodgers vd., 2009, s. 31-32).

Ardından 1948-1958 döneminde, sayıları sonradan sekize çıkan UÇÖ Temel Sözleşmelerinin beşi (örgütlenme ve toplu sözleşme özgürlügü, eşit ücret, zorla çalıştırmanın yasaklanması, ayrımcılığın önlenmesini konu alan 87, 98, 100, 105 ve 111 sayılı sözleşmeler) kabul edilmiştir. UÇÖ, böylece, insan haklarının işyerinde uygulanmasına ve korunmasına önemli bir yasal katkı sunmuş; bundan böyle ulusal ve uluslararası politikaların yasal zeminde sosyal hedefleri temel alacaklarını ve bu hedefleri destekledikleri ölçüde kabul göreceklerini ilan etmiştir. UÇÖ’nün belirlediği bu dayanak noktası; kurumsal otonomisini oluşturarak uluslararası yönetim yapısına eklemlenmesi için yeni bir modelleme sürecine girmesi anlamına gelmiştir. Bu çerçevede yapılan anayasal değişiklikler UÇÖ’nün uluslararası tüzel kişiliğini pekiştirmiş ve UÇÖ, Birleşmiş Milletler (BM) sisteminin ilk uzman kuruluşu olmuştur. Neredeyse 1990'lara kadar da UÇÖ düzenleyici faaliyetlerini ön planda tutmuştur (Perez, 2013, s.117-119). 
Altın Çağ olarak da adlandırılan bu dönemde birçok tavsiye kararı ve sözleşmenin yanı sıra UÇÖ'nün yayımladığı az sayıda bildirge, çalışma haklarının çerçevesini çizen önemli köşe taşları haline gelmiştir. Anayasa'ya da işlenen Philadelphia Bildirgesi’nin ardından farklı zamanlarda güncellenen Güney Afrika Irkçılık Politikasına İlişkin UÇÖ Bildirgesi (1964), Kadın Çalışanlara Fırsat Eşitliği ve Eşit Muamele Bildirgesi (1975) ile Çok Uluslu Şirketler ve Sosyal Politikaya İlişkin İlkeler Üçlü Bildirgesi (1977, sonrasında 2000 ve 2006'da gözden geçirilmiştir) bu dönemin ürünleridir. Daha sonraki döneme ait özel öneme sahip Çalışma Yaşamında Temel İlkeler ve Haklar Bildirgesi (1998) ile uygun iş gündemini UÇÖ’nün faaliyet çatısına dâhil eden Adil Bir Küreselleşme için Sosyal Adalet Bildirgesi (2008) ile UÇÖ çalışma haklarının çerçevesini belirginleştirmiştir. Sonrasında, özellikle iş sağlığı ve güvenliği alanında, bağlayıcı olmamakla birlikte pratikte kamu kesimi, sivil toplum ve özel sektör açısından yol gösterici nitelikte uygulama ilkeleri yayımlamaya başlamıştır (Rodgers, vd., 2009, s. 22).

\section{Neoliberal Dönem}

İlk Petrol Krizi'yle 1973’te başlayan yüksek enflasyon, ekonomik kargaşa ve sosyal gerilimler ile Altın Çağ' ın görece istikrarı sona ermiş, politik özgürlüğün ekonomik bağımsızlığı şahlandırmadığının anlaşılmasıyla, Üçüncü Dünya ülkelerinin, adaletsizliklerin tazmin edileceği yeni bir uluslararası ekonomik düzen talebi şiddetlenmiştir. Gelişmiş ülkelerdeki refah devleti kazançlarıyla tam istihdam taahhüdü gerilerken, sendikaların üyelerinin reel gelirini koruma yönündeki pazarlık faaliyetleri enflasyonu artırmış, sosyal diyaloğa dayalı gelir politikalarının çözüm üretememesi endüstriyel gerilimi tırmandırmıştır. ABD Doları endeksli sabit döviz kuru sisteminin terk edilmesiyle kurlardaki istikrar bozulmuş, gelişmekte olan ülkelerin büyük bir kısmı ödemeler dengesi krizine sürüklenirken bir grup Doğu Asya ülkesi (benzer politikalarla Çin ve Hindistan da daha yakın geçmişte benzer bir gelişme çizgisini yakalamıştır) ihracata dayalı büyüme modeli ile yüksek büyüme oranlarına ulaşmayı başarmıştır. Böylece 1980'lerin uluslararası ekonomi politikasına egemen olan neoliberal ideoloji; UÇÖ’nün manevra kabiliyetini sınırlandırmış; üçlü yapı tartış1ırken sendikalar pek dost canlısı olmayan ekonomik ve politik bir iklimle karşı karşıya kalmışlardır. Bu gelişmeler siyasal arenaya da yansımış, Latin Amerika ülkeleri adeta kayıp bir on yıl geçirirken Hong Kong, Güney Kore, Tayvan ve Singapur'dan oluşan Asya Kaplanları geliştirdikleri yeni teknolojilerle ciddi 
bir ihracat ivmesi yakalamış, Sovyet Bloğu'nun dağılması yeni sosyal sorunlar doğurmuştur. Doğu Avrupa'daki rejim değişikliği sonrasında UÇÖ, bağımsız işçi ve işveren sendikalarını güçlendirme faaliyetlerine girişmiş, en güçlü örgütlenmeyi Polonya'da sağlamıştır (Rodgers vd., 2009, s. 33-34).

Asgari ücret, sosyal güvenlik ve iş güvencesi gibi politika araçlarıyla işin niteliğini iyileştirmeyi hedefleyen düzenlemeler, 1980-90'lardan itibaren esnetilmeye başlanmış; Dünya Bankası ve İktisadi Kalkınma ve İşbirliği Örgütü (OECD) gibi örgütler bu kuralsızlaştırma politikasına öncülük etmişlerdir. Bu düzenlemelerle refahı artırmanın formel sektördeki işgücü maliyetlerini artırarak, talebi azaltacağı, dolayısıyla enformel sektörün işgücü arzını artırarak ücretleri baskılayacağı ileri sürülmüştür (World Bank, 1990, s. 63). Bu politikaların etkisiyle tüm dünyada işgücü piyasaları esnetilmiş, kırılgan işlerin sayısı artmış, kadınların yarı zamanlı, geçici, enformel işlerdeki temsil oranı yükselmiş, çalışma standartları aşağı çekilmiş, Doğu Avrupa gibi bölgelerde toparlanma gecikmiştir. UÇÖ ise bu gelişmeler karşısında tek sesli bir tepki verememiş; işverenler ve hükümetlerin bir kısmı, ekonomiye müdahalenin ekonomik etkinlik, büyüme ve istihdamı olumsuz etkileyeceğini savunurken, işçiler ve hükümetlerin geri kalanı kuralsızlaştırmaya direnmişlerdir (Rodgers vd., 2009, s. 104-105). UÇÖ ise ikinci grubun yanında yer alarak koruyucu istihdam kurumlarının ekonomik yararlarını ortaya koyan araştırmalar yapmış (O'Grady, June 1994, s. 255-278) ancak kural koyucu düzenlemelere girişmekte geç kalmış; yarı zamanlı çalışma, evde çalışma, özel istihdam büroları konulu 175, 177 ve 181 sayılı sözleşmeleri ancak 1994-1997 döneminde yayımlayabilmiştir. Söz konusu sözleşmelerin onaylanma oranı ise düşük seviyede kalmıştır. Ardından 2000'lerle birlikte gelişmiş ülkelerde işsizlik oranları azalırken, çalışma standartları tekrar gündeme gelmiş, başta Avrupa Komisyonu olmak üzere çeşitli uluslararası organlar atipik çalışanların korunması, iş yoğunluğunun azaltılması, iş güvencesi ve asgari ücretin düzenlenmesi gibi konular üzerinde çalışmaya başlamıştır (Rodgers vd., 2009, s. 105-106).

Diğer yandan yine bu dönemde ekonomik liberalizasyon politikaları sonucu ticaretin, yatırımların ve sermaye akımlarının önündeki engeller azaltılmış, Çin'de ve daha az oranda Hindistan'da uygulamaya koyulan ekonomik reformlar 1990'lardan itibaren küreselleşmenin daha da hızlanmasına yol açmıştır. Sovyet Bloğu'nun çöküşü küresel piyasa ekonomisinin hâkimiyetini pekiştirirken, küreselleşme komünizm engelinden kurtulmuştur. Merkezi planlamadan serbest 
piyasa ekonomisine geçen bu ülkelerdeki geçiş sürecini Bretton Woods Kuruluşları yönetmiş; bu kurumların finansal ve teknik yardımları, özelleştirme, faiz oranları, fiyatlar gibi temel ekonomik göstergelerde serbestleşme, iş gücü piyasalarında esnekleşme gibi yapısal değişikliklere uyum şartına bağlanmıştır. Piyasa ekonomilerinin iyi işlemesinin ön koşulu olan kurumsal, düzenleyici ve koruyucu altyap 1 ve politikalar ise ihmal edilmiştir. Sonuç olarak, bu ülkelerde daha önce görülmemiş boyutta yüksek sosyal maliyetli kitlesel işsizlik ve yoksulluk baş göstermiş ve UÇÖ bütün bu gelişmeler karşısında etkili bir varlık gösterememiştir (Rodgers vd., 2009, s. 199).

\section{Küreselleşmeye Karşı Sosyal Eleştiriler}

Neoliberal politikalara muhalif seslerin yükselmesiyle, 1990'ların ortalarından itibaren BM toplantılarında bu endişeler dile getirilmeye başlanmış, küresel düzeyde toplanan sosyal forumlarda uluslararası ticareti sosyal hükümlerle düzenleme ve sosyal gelişmeyi uluslararası politikaların merkezine oturtma çabaları hızlanmıştır (Rodgers vd., 2009, s. 213). UÇÖ’nün sosyal forum için hazırladığı, istihdam sorununun uluslararası düzeyde ele alınmasının gerekliliğini işaret eden ilk istihdam raporu (ILO, 1995, s. 198-200) yoğun ilgi görmüştür. Ertesi yıl yayımlanan, tam istihdam hedefi için hükümetler, işverenler ve sendikalara düşen sorumluluklara yer veren ve daha etkili olan ikinci rapor (ILO, 1996, s. 201-212) ise UÇÖ’nün küresel istihdam alanındaki ağırlığını pekiştirmiştir. Raporlarda istihdam sorununun çözümü için makroekonomik, gelir, işgücü ve ürün piyasası politikalarının bir arada kullanılmasının önemine değinilerek, gelişmekte olan ülkelerle ticaretin gelişmiş ülkelerdeki işsizliğin temel sebebi olduğu görüşü reddedilmiştir. Ardından UÇÖ; gözlemci sıfatıyla IMF Geçici Komitesi, düzenli katılımcı sıfatıyla OECD’nin yanı sıra G7 (sonrasında G8) ülkelerinin çalışma bakanları toplantılarına katılmaya başlamıştır. Asya Finansal Krizi sonrasında uygulanan 1980'lerinkine benzer yapısal uyum programları krizin sosyal maliyetlerini ağırlaştırınca, makroekonomik tartışmalara girmeksizin UÇÖ, kriz öncesi dönemlerde sosyal diyalog ve sosyal korumaya yönelik kurumsal altyapının sağlamlaştırılmasının önemine dikkat çekmiştir (Lee, 1998, s. 61-62).

Diğer yandan, uluslararası ticarette sosyal hüküm tartışmaları, başlangıçta ABD’nin, gelişmekte olan ülkelerin muhalefeti nedeniyle kuruluşu sonrasında Dünya Ticaret Örgütü'nün (DTÖ) gündeminden çıkmış; 1996'daki DTÖ Bakanlar 
Toplantısı'nda alınan kararla UÇÖ uluslararası çalışma standartlarının belirlenmesi ve düzenlenmesinden sorumlu kuruluş olarak tescillenmiştir (WTO, 1996). DTÖ’nün 1999'da Seattle'daki Bakanlar Toplantısı bir yandan küreselleşmeyi reddedenlerin protesto gösterilerine sahne olurken; Kuzey ve Güney cephesindeki fikir ayrılıkları nedeniyle planlanan yeni görüşme turları başlatılamamıştır. UÇÖ Başkanı, eş zamanlı bildirisinde; eşitsizlik ve adaletsizlikler küresel toplumca çözümlenmeden uluslararası entegrasyonun kabul görmeyebileceğini, küreselleşme ile ilgili verilere göre eşitsizliklerin arttığını belirterek; uygun iş çerçevesinde oluşturulacak uluslararası girişimle küreselleşmenin sosyal etkileriyle baş etmeyi önermiştir (ILO, 01 December 1999).

Seattle' daki görüşmelerin sonuçsuz kalması neticesinde UÇÖ harekete geçmiş ve bünyesindeki çalışma grubunun adı küreselleşmenin sosyal boyutunu içerecek şekilde değiştirilmiştir (ILO, March 2000, s. 4-5). Ardından aynı isimle oluşturulan komisyon, ayrıntılı bir rapor tanzim ederek UÇÖ’nün ekonomik ve sosyal politikalarda küresel aktör olarak gücünü pekiştirmeyi hedeflemiştir (ILO, November 2001, s. 1). Söz konusu komisyon yayımladığı raporda, sayısız faydası olmakla birlikte birçok dengesizliği de içinde barındıran küreselleşmenin, şu anki haliyle sürdürülemez olduğunu; kazandırılacak güçlü bir sosyal boyutla küreselleşmenin yönünün değiştirilebileceğini, bunun uygun iş gündemi ve belirlenecek küresel amaçlarla mümkün olduğunu vurgulamıştır (ILO, February 2004, s. ix-xv).

Diğer yandan, eş zamanlı olarak finansal krizlerin sayısı ve şiddeti de artmış, krizlerin yıkıcı maliyetlerinin yol açtığ 1 küreselleşmeye sosyal bir boyut kazandırma ihtiyacıyla UÇÖ tekrar uluslararası arenada etkili olmaya başlamıştır. Birçok ülkeyi içine alan, çok katmanlı ekonomik ilişkiler ağı yaratan küresel üretim sistemi hızla geliştikçe, başta dışsallaştırılan hizmetler sektörü olmak üzere sınır ötesi işlemlerde ciddi düzeyde artış yaşanmış, çok uluslu şirketlerin piyasa hâkimiyeti ve erişim güçleri artarken, finansal küreselleşme katlanarak büyümüştür (Rodgers vd., 2009, s. 34). Serbest piyasa ekonomisi evrensel standardı oluştururken, ülkeler arasındaki yoğun sermaye akışı finansal piyasaları kuralsızlaştırmıştır. Bu bağlamda, ihtiyaçlar doğrultusunda kurallar oluşturma, sosyal hakları teşvik edecek yeni firsatlar yaratma ve uluslararası çalışma standartlarını çok disiplinli olarak ele alma ihtiyacı artmıştır (Hansenne, 1994, s. 4).

$\mathrm{Bu}$ gelişmeler, devletlerin ulusal ekonomileri kontrol ve düzenleme güçlerini azaltırken, küresel yönetim araçları geri kalmış, ancak sosyal meselelere duyarlı 
sivil toplum güçlenmeye başlamıştır. Uluslararası sosyal politikaları, 1980’ler sonrasında uygulanan ekonomi politikalarının yarattığı sosyal felaketler ışığında tekrar değerlendirme ihtiyacıyla, BM bünyesinde, ekonomi politikalarının sosyal sonuçlarının tartışıldığı, UÇÖ’nün etkinliğini artıran bir dizi konferans düzenlenmiştir. Bu konferanslar sonunda alınan kararlar; UÇÖ gündemi ile büyük ölçüde örtüşen, güçlü bir uluslararası işbirliği altında, işsizlik ve yoksulluğun ortadan kaldırılması ile sosyal gelişme için uygun çevre ve kaynakların, eğitimde ve iş hayatında fırsat eşitliğinin sağlanmasını hedefleyen; bir tarafta haklar ve standartlar, diğer tarafta kalkınma ve yoksulluğun önlenmesini içeren bütünlükçü bir yaklaşım ihtiyacı doğurmuştur. Bu konferanslar neticesinde UÇÖ; teknik uzman komiteleri aracılığıyla bazı ülkelerin istihdam politikalarını gözden geçirmiş; sosyal hüküm çıkmazından kısmen de olsa uzaklaşarak zorunlu çalışma haklarının gördüğü uluslararası kabulden güç almak suretiyle, bu kapsamdaki sözleşmelerin imzalanması yönündeki çabalarını artırmıştır (Rodgers vd., 2009, s. 217-220).

\section{Çalışma Hayatına İlişkin Temel İlkeler ve Haklar UÇÖ Bildirgesi (1998)}

UÇÖ’nün özel önemdeki düzenlemelerinden Çalışma Yaşamında Temel İlkeler ve Haklar Bildirgesi'ne giden süreçte; BM'in 1995'te Kopenhag'da gerçekleştirdiği Sosyal Gelişme Konferansı, temel çalışma haklarının uluslararası boyutta tanınmasında önemli bir basamak olmuştur. Burada kabul edilen eylem planı 1994'te belirlenen haklara çocuk işçiliğinin yasaklanmasını da ekleyerek, bu hakları doğrudan UÇÖ Sözleşmeleri ile ilişkilendirmiştir (UN, 6-12 March, s. 59). Konferansta kabul edildiği üzere yoksullukla mücadelede ulusal eylemin yanı sıra uluslararası işbirliğine de ihtiyaç duyulmakta, bunun en etkili yolu tam istihdamı sağlamaktan geçmektedir (UN, 6-12 March, s. 11). Daha sonra OECD'nin temel çalışma hakları ile uluslararası ticaret arasındaki bağı irdeleyen 1996 tarihli raporu; büyük ölçüde kabul gören bir grup çalışma hakkını zorunlu çalışma standartları olarak isimlendirmiştir. Rapor; gelişmekte olan ülkelerin bu standartların rekabet güçlerini azaltacağı yönündeki endişelerinin yersiz olduğu, bilakis bu hakların uzun dönemde tüm ülkelerin ekonomik performanslarını yükseltebileceği tespitinde bulunmuştur (OECD, 1996, s. 10-14). Ardından DTÖ'nün Aralık 1996'da Singapur'da toplanan ilk bakanlar düzeyindeki konferansında temel çalışma hakları ilk kez referans alınmıştır. Sonuç bildirgesinde, temel çalışma haklarına saygı duyulacağı, UÇÖ'nün bu hakların belirlenmesinde yetkili kuruluş olduğu ve korumacı amaçlarla 
kullanılmaması gereken bu hakların ekonomik gelişmeye paralel olarak gelişebileceği vurgulanmıştır (WTO, 1996). Sonrasında uluslararası kamuoyundan temel çalışma hakları konusunda yetkili kuruluş olarak aldığı bu destekle UÇÖ, 1998'de düzenlenen 86. oturumda Çalışma Yaşamında Temel İlkeler ve Haklar Bildirgesi'ni kabul etmiştir.

Değişen küresel şartlara UÇÖ’nün ilk sistematik cevabı olan bildirge; UÇÖ’nün standart koyucu fonksiyonunun bir ürünü olarak, 1986-1994 dönemini kapsayan Uruguay GATT Görüşmeleri ile 1995'te kurulan DTÖ bünyesinde gerçekleştirilen uluslararası ticaretin serbestleştirilmesi tartışmalarından etkilenmiştir. Kuruluşunun 75. yılında düzenlenen konferansta UÇÖ’nün içyapısına yönelik tartışmalar ağırlık kazanırken, UÇÖ’nün kural koyma faaliyetinin gelecekteki önemi vurgulanmış, küreselleşme dalgasında sosyal hakları daha güçlü şekilde teşvik edecek firsatların aranması, kural koyma faaliyetinin değişen ihtiyaçlara daha iyi uyarlanması, uluslararası ticaretle sosyal haklar arasında sinerji yaratılması istenmiştir (Perez, 2013, s. 119-122).

Korumacılığa sebep olma tehlikesi nedeniyle Misır, Pakistan, Meksika gibi bir takım gelişmekte olan ülkelerin itirazlarına karşın 1998'de kabul edilen Çalışma Hayatına İlişkin Temel Haklar ve İlkeler Bildirgesi, küresel ekonomiye evrensel bir sosyal zemin kazandırmaya yönelik ilk sistematik yaklaşım ve politika uygulaması niteliğindedir. Söz konusu sosyal zemin, ertesi yıl oybirliğiyle kabul edilen 182 sayılı "En Kötü Biçimlerdeki Çocuk İşçiliğinin Yasaklanması Sözleşmesi” ile pekiştirilmiştir. Bu konferansların UÇÖ üzerindeki bir başka etkisi, zor olmakla birlikte, UÇÖ’nün tüm birleşenlerinin, temel çalışma hakları, istihdam ve gelir, iş sağlığ ve güvenliği ile sosyal diyalogdan oluşan dört temel alandaki taleplerini dikkate alarak, onları ortak paydada buluşturacak daha bütünleşik bir referans çerçevesi ihtiyacının kabul edilmesidir (Rodgers vd., 2009, s. 221-222). Bu referans çerçevesi 1999'daki Uluslararası Çalışma Konferansı'nda UÇÖ’nün temel hedefi olarak belirlenen bu dört stratejik hedefi bir araya toplayan uygun iş (decent work) olmuştur. Bu yaklaşımın temelinde; iktisadi, sosyal ve çevresel amaçlara ekonominin insanileştirilmesiyle ulaşılması fikri yer almaktayd1 (ILO, June 1999, s. 1-2).

Çalışma Yaşamında Temel İlkeler ve Haklar Bildirgesi'nde; dört temel hak kategorisinde (örgütlenme ve toplu pazarlık hakları ile zorla çalıştırma, çocuk işçiliği ve ayrımcılığın yasaklanması) yer alan temel UÇÖ sözleşmelerindeki ilkelerin uluslararası kamuoyunda referans kabul edilerek 2. madde uyarınca 
sözleşmeleri imzalamayan üyelere dahi sorumluluk yüklediği belirtilmiştir. Burada ülkeler, UÇÖ’ye katılmakla UÇÖ Anayasası'nda yer alan değer, ilke ve hakları onayladıklarından, söz konusu ilkelere saygı duymak, onların farkına varmak ve uygulanmalarını teşvik etmekle yükümlüdür. Bildirgenin 3. maddesine göre UÇÖ'nün görevi ise; üyelerin bu sözleşmeleri imzalamasına, imzalayacak durumda olmayan üyelerin Anayasa'da sayılan ilkelere bağlı kalmasına ve ekonomik ve sosyal gelişme için uygun bir ulusal ortam yaratılmasına yönelik çabalarına destek olmaktır. Bildirge katı şekilde ihtiyari bir gözlem mekanizması da oluşturmuştur. Buna göre, temel sözleşmeleri henüz imzalamamış olan üyelerin çabaları yıllık olarak değerlendirilmekte, dört temel hak kategorisi ise küresel düzeyde yine yıllık olarak raporlanmakta ve konferansa sunulmaktadır (ILO, 18 June 1998, s. 6-12). UÇÖ yönetimi tarafından da ifade edildiği gibi, bildirgede say1lan temel sözleşmeler küresel ekonomiye sosyal zemin oluşturma işlevi görmüştür (Charnovitz, 2000, s. 162). İhtiyaç duyulduğunda yenilerini ekleme düşüncesiyle, bildirgede temel sözleşmeler numarası verilerek doğrudan sayılmamış olup; 2019 itibariyle sayıları sekize (87, 98, 29, 105, 138, 182, 100 ve 111 sayılı UÇÖ Sözleşmeleri) çıkmıştır (ILO, 2019b).

Bildirgenin ortaya çıkış sürecinde işveren kesimi ve devletler, yeni düzenlemelerle yasal yükümlülüklerin artırılmamasını önemserken; işçi kesimi hali hazırda imzalanmış sözleşmelerin getirdiği garantilerin zayıflatılabileceği endişesini dile getirmiş; diğer yandan Kuzey ve Güney arasında ticaret meselesi etrafında devam eden tartışmalar hız kesmeden devam etmiştir (Coxson, 1999, s. 499-500). Bu bağlamda 5. madde ile getirilen çalışma standartlarının korumacı amaçlarla kullanılamayacağına yönelik düzenleme, bildirgenin kabulünde önemli bir rol üstlenmiştir (ILO, 18 June 1998, s. 8).

Bildirge, temel sözleşmelerin imzalanma oranına ciddi bir ivme kazandırmış, Kopenhag Konferansı ile başlayan süreçte, sözleşmelerin imzalanma oranı \%68 artmış (ILO, 2012, s. 13); günümüzde ise 187 üyenin 149'u temel sözleşmelerin tümünü imzalamıştır (ILO, 2019). Bildirge ayrıca, teknik destek amacıyla kullanılmak üzere bağışçı ülkelerin UÇÖ’ye kaynak aktarımını hızlandırmıştır. Bildirge'nin bir başka başarısı ise temel çalışma haklarının kavram ve içerik olarak uluslararası kamuoyunca referans alınmasını sağlamasıdır; böylece UÇÖ’nün statüsü yükselmiş, görünürlüğü artmıştır (ILO, 2010, s. 2). Sonuçta temel çalışma haklarını referans alan diğer uluslararası örgütler ve çok uluslu şirketlerce imzalanan dokümanların sayısında hızlı bir 
yükselme yaşanmıştır (ILO, 2012, s. 92-97). Bütün bu gelişmelere karşın imzalanan sözleşmeler; özellikle hukuk devleti vasfını henüz kazanamamış, kurumsal alt yapısı yetersiz, enformel ekonominin yaygın olduğu ülkelerde, ulusal yasa ve uygulamalarda fazla bir karş1lık bulamamaktadır (ILO, 2012, s. 46-50). Diğer yandan, temel sözleşmeler içerisinde toplu çalışma haklarına ilişkin olanlar en az oranda imzalanmakta, bu kategorideki haklara teknik yardım amacıyla ayrılan UÇÖ kaynağı da görece düşük kalmaktadır (ILO, 2012, s. 17, 56-60).

\section{Milenyum ve Yeniden Yapılanma Sürecinde UÇÖ}

\section{Yeni Yol Haritası: Uygun İş}

UÇÖ Başkanı Somavia (1999-2012) göreve başladığında, UÇÖ için hazırladığı dört stratejik amaç çerçevesinde şekillenen yeni yol haritasını ilan etmiştir. Somavia temel çalışma haklarının teşviki, herkes için uygun istihdam, gelir ve kapsamlı sosyal koruma firsatı ile güçlü bir sosyal diyalog olarak sıralanan amaçların; uygun iş etrafında birleşmesini önermiştir (ILO, 22 March 1999). Ardından Haziran 1999'da uygun iş daha detaylı şekilde tanımlanarak, UÇÖ’nün karşı karşıya olduğu iki temel problem karşısında yol gösterici olacağı ileri sürülmüştür. Bu sorunlardan ilki, UÇÖ’nün Philadelphia Bildirgesi’nden bu yana sürdürdüğü öncelik belirlemeksizin daha geniş kapsamlı programlar hedefleme eğiliminin UÇÖ’nün kapasitesini ve kaynaklarını aşarak etkinlik kaybına ve parçalanmaya yol açmasıdır. Diğer sorun ise Soğuk Savaş'ın sona ermesinin, UÇÖ’nün üçlü yapısı üzerindeki fikir birliğini kırılganlaştırmasıdır (ILO, June 1999, s. 3).

Bu bağlamda, 1999 sonrasındaki UÇÖ politikalarında, uygun iş gündemi öncelik kazanmıştır. İşçi ve işveren temsilcilerinin, birbirlerinden farklı nedenlerle de olsa (işçi kesimi enformel istihdamın çalışma haklarını yükseltme çabalarını baltaladığını ve kayıt altına alınması gerektiğini savunurken işveren kesimi çalışma ve vergi mevzuatına uygun çalışan firmalara karşı haksız rekabete sebep olduğunu ileri sürmekteydi) enformel istihdamın kurallara bağlanmasını istemeleri üzerine; UÇÖ, 2002' de enformel istihdam için de uygun iş önerileri getiren bir strateji belgesi hazırlamıştır (Rodgers vd., 2009, s. 106-107). Strateji belgesi hedefine tam olarak ulaşamasa da bu belgeyle, çalışan haklarının farkındalığının artırılması, sosyal güvenliğin genişletilmesi, iş sağlığı ve 
güvenliği önlemlerinin maliyetini düşürecek yerel çözümler üretilmesi suretiyle enformel sektördeki iş kalitesinin artırılması ile küçük ve orta boy işletme sahiplerinin artan iş kalitesinin kendi menfaatlerine olacağı yönünde ikna edilmelerinin hedeflenmiş olması (ILO, 2002, s. 68) önemlidir.

Konjonktürel olarak ise 2000 sonrasında; küresel gelir artmış; mutlak yoksulların sayısı azalmış; bununla birlikte hem küresel düzeyde hem de birçok ülkenin kendi içinde bölgesel eşitsizlikler derinleşmiş; gelişmekte olan ülkelerin ekonomik performansları arasındaki makas açılmıştır (Global Deal, 2018, s. 10). Küreselleşmenin adil olmadığına inanan kesim Bretton Woods Kuruluşları ile DTÖ'ye sorumluluk yüklerken; sosyal sorunlara çözüm arayışındaki UÇÖ, küresel düzeyde bütünleşik politikalar üretmek üzere çalışmalarını sürdürmüştür (ILO, November 2000, s. 1-10). Küreselleşmenin kabul edilemez ve politik olarak sürdürülemez mahiyetteki ekonomik ve sosyal etkileriyle çözüm önerilerini değerlendiren UÇÖ Komisyonu, bir kez daha uygun işi işaret etmiştir (ILO, February 2004, s. 110-115).

Bu bağlamda UÇÖ; yatırımlar, istihdam ve büyüme alanlarında ahenkli bir politika çerçevesi oluşturmak için uluslararası finans kuruluşları ile BM'nin ilgili kurumlarıyla ortak çalışmalar yürütmektedir. Örneğin UÇÖ ve DTÖ ortaklığında yürütülen ticaret ve istihdam konulu bir araştırmada; ticaret politikaları ile sosyal politikaların etkileşim halinde olduğu, aradaki uyumun artmasıyla ticari reformların büyüme ve istihdamı olumlu etkileyebileceği sonucuna varılmıştır (Jansen ve Lee, 2007, s. 10). BM de Milenyum Deklarasyonu'nun ilanından 5 yıl sonra önemini teslim ederek insan onuruna yakışır uygun işi Milenyum Hedefleri'ne giden yolda ulusal ve uluslararası politikaların temel amacı ilan etmiştir (UN, 24 October 2005, s. 11).

Diğer yandan UÇÖ uluslararası kamuoyunu uygun iş çatısı altında eyleme geçirmek üzere yoğun gayret göstermiş; BM, Dünya Ekonomi Formu ve Dünya Sosyal Formu toplantıları gibi çeşitli platformlarda uygun işi sıklıkla gündeme taşımıştır. Bu gayretlere karşın BM'nin Milenyum Deklarasyonu'nda (Eylül 2000) itici güç olarak uygun iş ve istihdam yerine küreselleşmeye odaklanılmış, 2015 için bu çerçevede belirlenen Milenyum Kalkınma Hedefleri, Dünya Sosyal Formu'na (Haziran 2000) kıyasla daraltılmıştır. Burada Bretton Woods Kuruluşları, OECD ve BM; uluslararası sosyal gündemi yeniden tanımlayarak Dünya Sosyal Formu'nda belirlenen yoksulluğun azaltılması, yeni işlerin yaratılması ve sosyal entegrasyon hedeflerinden sadece ilkini açık bir hedef 
olarak ilan etmişler; ancak sivil toplum kuruluşları ile gelişmekte olan ülkelerin büyük oranda itirazıyla karşılaşmışlardır (Rodgers vd., 2009, s. 226-227).

Uygun iş gündeminin BM sistemine dâhil olması biraz daha zaman almıştır. Başlangıçta uygun iş gündemi Milenyum Hedefleri arasında kendisine güçlü bir yer edinememiş, sadece Milenyum Deklarasyonu'nda kalkınma ve yoksulluğun önlenmesi başlı̆̆ 1 altında gençlere uygun ve üretken iş firsatı yaratmanın öneminden bahsedilmiştir (United Nations, 8 September 2000, s. 5). Ardından uygun iş önce milenyum hedefleri çerçevesinde ulusal ve uluslararası politikaların merkezine alınmış (United Nations, September 2005, s. 11); BM Genel Sekreteri'nin tavsiyesi üzerine (United Nations, 2006, s. 6), 15 Ocak 2008 'de "kadınlar ve gençler dâhil herkes için tam ve üretken istihdam ve uygun işi sağlamak" Milenyum Kalkınma Hedefleri’nden ilki olan "Yoksulluğu ve Açlığg Ortadan Kaldırma” hedefine alt amaç olarak eklenebilmiştir (United Nations, 15 January 2008). Böylece UÇÖ; BM kalkınma gündemindeki kurumsal yerini sağlamlaştırmış; uluslararası bir kurum olarak gittikçe artan oranda küreselleşmenin sosyal boyutu ile ilişkilendirilmeye başlanmıştır.

\section{Adil Bir Küreselleşme İçin Arayışlar: Sosyal Adalet Deklarasyonu ve 2008 Finansal Krizi}

Uygun iş gündeminin UÇÖ bünyesinde resmi bir dokümana dönüşmesi UÇÖ’nün uluslararası kamuoyundan gördüğü kabul ile eş zamanlı olarak gerçekleşmiş; Adil Bir Küreselleşme İçin Sosyal Adalet Deklarasyonu 10 Haziran 2008'de kabul edilmiştir. Kasım 2004'te başlayan hazırlıklar, üçlü yap1 içerisinde sürdürülmüş, uzun müzakereler neticesinde nihai metne ulaşılabilmiştir. Girişte, UÇÖ’nün sürekli değişen bir çevrede gelişme ve sosyal adaleti sağlamada oynayabileceği rol vurgulanmış; sonrasında bildirge, birbiriyle bağlantılı ve birbirini destekleyen, birbirinden ayrılamaz ve eşit önemdeki dört stratejik hedef üzerinde şekillenmiştir. Burada amaç, kendileri için en uygun olan hedefi seçip uygulamak yerine ülkelerin hedefleri topyekün benimsemelerini sağlamaktır.

Bu bağlamda ilk olarak sürdürülebilir kurumsal ve ekonomik bir çerçevede istihdamı artırmak amaçlanmaktadır. İkinci hedef; ulusal düzeyde alınacak önlemlerle sosyal güvenliğin modern hayata uyarlanarak herkesi kapsayacak şekilde şekillendirilmesidir. Sonraki hedef olan sosyal diyaloğun üçlü yap1 içerisinde artırılması; bildirgedeki stratejik hedeflerin sağlanmasında en uygun 
araç olarak kabul edilmektedir. Son hedef olan temel çalışma ilke ve haklarına sayg1 gösterilmesi (toplanma ve örgütlenme özgürlügüne ayrıca vurgu yapılmaktadır); bildirgedeki diğer stratejik hedeflere tam olarak ulaşılabilmesi için de gerekli olduğundan özel bir konuma sahiptir. Diğer yandan bildirgeye göre, temel çalışma ilke ve haklarının ihlâli, ticarette karşılaştırmalı üstünlük sağlamanın meşru bir yolu olamayacağı gibi bu ilke ve haklar korumacı ticari amaçlarla da kullanılamaz. Bildirge ayrıca, cinsiyet eşitliği ve ayrımcılığın önlenmesi ilkesini, bu dört stratejik hedefin ortak ilgi alanı olarak belirlemiştir. Ülkeler bu amaçlara; ulusal şartlar, ihtiyaçlar ve sosyal tarafların öncelikleri doğrultusunda, diğer UÇÖ üyeleriyle işbirliği içerisinde ve uluslararası çalışma standartlarına saygı çerçevesinde, kendilerinin belirleyecekleri yollarla ulaşacaktır (ILO, 10 June 2008, s. 1-22).

Günümüzde UÇÖ’nün temel hedefinin ifade biçimi haline gelen uygun iş; küresel düzeyde fikir birliği oluşturmanın da en önemli aracı haline gelmiştir. Bir yandan gelişmekte olan ülkelerin istihdam planlarını kalkınma hedefleri içerisine yerleştirmelerine yardım ederken; bir yandan da gelişmiş ülkeleri de tatmin edecek şekilde temel çalışma haklarını küresel ekonomide teşvik etmenin yoluna dönüşmüştür. (Rodgers vd., 2009, s. 223-224). Ampirik olarak değerlendirilmesi güç bir kavram olsa da UÇÖ’ye çalışmaları için daha kapsamlı bir çerçeve sunan uygun iş; UÇÖ’nün küresel bir oyuncu olarak konumunu sağlamlaştırmıştır. Diğer yandan politik açıdan yüksek bir başarı elde etmiş, Uluslararası Sendikalar Konfederasyonu'nun anayasasına temel hedef olarak girmiştir (International Trade Union Confederation, May 2014, s. 5).

Uygun iş stratejisi sonrasında UÇÖ uluslararası gelişmeleri yakından takip etmeye devam etmiş; 2008'de yaşanan küresel finansal krizin ardından Haziran 2009'da UÇÖ Genel Konferansı'nda Küresel İşler Paktı kabul edilmiştir. Krizin sosyal etkileri karşısında yatırımlar ve sosyal koruma odaklı iyileşme önerilmiş; işsizlik, eksik ve enformel istihdam gibi işgücü piyasası sorunları masaya yatırılmış, istihdam boyutu eksik kalan çözüm önerilerinin krizi derinleştireceğine dikkat çekilmiştir. Küçük, orta ölçekli, mikro işletmelerdeki ve emek yoğun sektörlerdeki istihdam ve yatırımlar ile çalışanların becerilerini artıracak; kırılgan işlerde ve enformel çalışanlara yönelik sosyal güvenlik sistemlerini kuvvetlendirecek çözümler üzerinde durulmuştur. Burada altı çizilen dört temel alan; reel ekonomi ve uygun işlere denetmenlik yapacak bir finansal alt yapı; etkin, iyi işleyen ve kurallara bağlı piyasa ekonomisi; düşük karbon salınımlı, 
çevre dostu bir ekonomi ile istihdam ve sosyal korumayı merkeze alan kalkınma çerçevesidir (ILO, 19 June 2009, s. 1-15).

Uygun iş ile bağlantılı olarak yine 2008 krizi sonrasında UÇÖ'nün öncülüğünde BM Sosyal Koruma Tabanı Girişimi hayata geçirilmiştir. Mutlak yoksulluğu önlemeye yönelik ihtiyaç sahiplerine asgari sağlık ve gelir güvencesinin sunulmasının önemine vurgu yapan girişim; uluslararası işbirliğinin gerekliliğinin yanı sıra sosyal korumada tabanı her ülkenin kendisinin belirleyeceğinin altını çizmiştir. BM İnsan Hakları Evrensel Beyannamesi ile 102 sayılı UÇÖ Sözleşmesi'ne atıf yapan girişime göre, sağlık sigortası, okullarda beslenme, kamu hizmeti, garantili istihdam programları ya da dezavantajlı gruplara yönelik doğrudan gelir transfer programları temel müdahale alanlarıdır. Sosyal koruma sistemlerinin sürdürülebilirliğinin öneminin altını çizen girişim, uzun dönemde gerekli yasal alt yapının oluşturulmasını istemiştir (ILO ve World Health Organization, November 2009, s. 1-5). Ardından UÇÖ 2012'de 202 sayılı Sosyal Güvenlik Tabanları Tavsiyesi'ni kabul ederek kapsayıcı iş gücü piyasalarına, kapsamlı, eşitlikçi ve sürdürülebilir sosyal koruma sistemiyle ulaşılabileceğini vurgulamıştır (International Monetary and Financial Committee, 14 October 2017, s. 5).

Finansal kriz sonrasında küresel stratejilerin oluşumunda başat rolü, gelişmiş ve bir grup gelişmekte olan ülkeden oluşan G20 üstlenmiştir. G20 devletlerin egemenlik haklarına saygılı olmak şartıyla, asgari ekonomik hedefler ve geri bildirim usulleri belirlerken; küreselleşmenin sosyal boyutunun da içerilmesi için UÇÖ’nün uygun iş gündemi, Küresel İşler Paktı ve BM’nin Milenyum Kalkınma Hedefleri'nin referans alınmasını istemektedir. Bu doğrultuda iş yaşamında temel haklara saygı duyulması, uygun işlerin yaratılması ve her ülke için sosyal koruma tabanlarının belirlenmesi yollarıyla yoksullukla mücadele edilmesi temel öneriler arasındadır. G20, finansal politikaların sosyal politikalarla uyum içerisinde oluşturulmasını, UÇÖ ile daha yakın bir işbirliği geliştirilmesini önemsemekte; bu bağlamda, temel ilke ve kararlarında, ekonomik krizden çıkış reçetelerinde, UÇÖ’nün önerilerini dikkate almaktadır. UÇÖ’nün önerdiği, temel çalışma hakları, uygun iş, asgari sosyal güvenceler gibi sosyal parametrelerin G20'nin küresel yönetim sisteminde yer alması; sistemsel istikrarı hedefleyen finansal ve ekonomik vaatlerde, UÇÖ değerlerine de yer verilmesi anlamına gelmektedir (Perez, 2013, s. 131-139). Bu bağlamda UÇÖ standartları ile uygun iş gündemi, başta G20 olmak üzere küresel politika 
yapıcılarının referans noktası haline gelmiştir (Viilup ve Przetacznik, January 2016, s. 4).

Geçmişten günümüze taşıyarak zenginleştirdiği diğer uluslararası örgütlerle ortaklık serüveni ile ikili ilişkilerin güçlendirilmesi günümüzde de UÇÖ’nün reform gündeminin önemli bir parçasıdır (ILO, 2013, s. 22). UÇÖ’nün ve Uluslararası Sendikalar Konfederasyonu ile Uluslararası İşveren Örgütü’nün; Uluslararası Finans Kurumu (IFC), BM'in bağlı kuruluş ve programları, IMF ve Dünya Bankası ile yürüttüğü ortak projeler; çevre haklarında UÇÖ’nün de söz sahibi olmasını, sosyal diyalog, istihdam yaratan büyüme ve dezavantajlı gruplar için sosyal koruma zemininin, işbirliğine gidilecek politika alanları olarak belirlenmesini sağlamıştır. Diğer yandan UÇÖ, yarı kamusal yarı özel ulus aşırı girişimlerde de etkin rol almaktadır. Küresel değer zincirleri yönetimine katkı amacıyla çeşitli projelere teknik destek sunmakta, oluşturduğu danışma merkezlerinde firmalara bilgi sağlamaktadır. Bu bağlamda, UÇÖ’nün 2008 sonrasında ana ilke ve değerleri doğrultusunda; özel sektör, vakıflar, akademik çevreler ve sivil toplum ile proje geliştirme, finansman, danışmanlık, bilgi değişimi gibi amaçlarla ortaklıklara yoğunlaştığ görülmektedir (Jakovleski vd., 2019, s. 92-95, 100).

\section{Küreselleşmeyi Yapılandırma Sürecinde UÇÖ}

Dünya ekonomisi 20. Yüzyıl'ın dördüncü çeyreğinden itibaren artan şekilde bütünleşme eğilimindedir. Üretim ve işbölümü küreselleşerek hiyerarşik bir ilişki oluşturmuş, ülkeler arasındaki teknolojik donanım farkı sürmüş, piyasa koşulları değişmiş ve artan rekabet yeni özellikler kazanmıştır. Bu rekabetçi yapı, çalışma yaşamı üzerinde önemli olumsuz etkiler doğurmuş; ülkeler arasındaki ve ülkelerin kendi içlerindeki vasıflı ve vasıfsız işgücü ayrımı belirginleşmiş; elde edilen hasılanın dengeli paylaşılamaması, sosyal sorunlara yol açmıştır.

Dünya ekonomisinin bu yapısı içinde gelinen noktada; 3,3 milyarı bulan küresel istihdamın çoğunluğu ekonomik güvencesi olmayan, uygun iş niteliği taşımayan işlerde çalışmakta, küresel işgücünün yaklaşık \%60'1 enformel şartlarda istihdam edilmektedir. Orta gelirli ülkelerde çalışan yoksulluğu gerilemekte, ancak orta ve düşük gelirli ülkelerde çalışanların halen dörtte biri mutlak ya da görece yoksul statüsünde sayılmaktadır. Küresel nüfusun \%55'inin herhangi bir sosyal güvencesi bulunmamakta, küresel düzeyde reel ücretler artsa da dünyanın birçok bölgesinde ücretler çalışanların ihtiyaçlarını karşılamakta 
yetersiz kalmaktadır. İşsizlik 2008 sonrasında azalmakta ancak halen işsizlerin sayıs1 170 milyonu geçmekte, küresel genç nüfusun beşte biri ne istihdamda, ne eğitimde, ne de yetiştirme faaliyetinde yer almaktadır (ILO, 2019c, s. 1-24).

Ülkeleri tüm aktörleriyle topyekûn bir rekabete sürükleyen ekonomik küreselleşme ve doğurduğu sonuçlar, çalışma ilişkileri alanında aktörleri çok katmanlı ilişkiler ağında politika üretmeye zorlamaktadır. Küreselleşme sürecinin özellikle erken döneminde daha belirgin olarak, devletlerin ulusal politikaları bağımsızca belirleme gücünün azalmasıyla küresel aktörlerin etkinliği artmış, dikkatler uluslararası sosyal politikalara yönelmiştir (Delican, 2017, s. 9-28). 2008 krizi sonrasında ticaret, yatırımlar, iş gücü, çevre ve finans piyasaları kaynaklı suistimal ve adaletsizlikleri önlemede devletlerin bireysel çabalarının yetersiz kaldığını, uluslararası düzlemde politikalara ihtiyaç olduğunu ileri süren görüşler sıkça dile getirilmeye başlanmıştır (Rodgers vd., 2009, s. 237-239).

Uluslararası düzlemde ise UÇÖ’nün ayrıcalıklı bir konumu vardır. Küresel politikaları oluşturanlar; çok uluslu ve bölgesel finans ve ticaret kurumlarının ekonomik araçlarından yoksun olan UÇÖ’nün, politik işbirliğine, evrensel üyeliğin getirdiği uluslararası meşruiyete ve üçlü yapıdan kaynaklı sosyal nüfuza gereksinim duyduğundan; değerleri ve otoritesi UÇÖ’ye, tarihsel dönüm noktalarında, stratejik bir rol oynama firsatı vermektedir. Böyle zamanlarda, politika ve standart oluşturma, teknik işbirliği gibi araçlar kullanarak UÇÖ, ekonomik ve sosyal olarak bütünleşik bir çerçevede kapsamlı yaklaşımlar sergileyebilmektedir (Rodgers vd., 2009, s. 9, 12, 19, 235-236).

Bununla birlikte yaptırım gücü sınırlı olduğundan UÇÖ, politika geliştirme ve uygulama süreçlerinde önemli zorluklarla karşılaşmaktadır. Diğer yandan küresel aktörlerin etkisinin her alanda hissedilmesine karşın küreselleşmenin derinleşmesiyle çalışma hayatına ilişkin kurumlar ve aktörler yeni şartlara göre kendilerini yapılandırmakta, UÇÖ'nün geleneksel birleşenlerinden devletler temel politikalar üretebilmektedir (Delican, 2017, s. 30). Bu da UÇÖ’ye, ürettiği sosyal politikaların etkisini, devletlerle yapacağı işbirliği aracılığıyla artırma firsatı vermekte; böylece var olan sınırlar içerisinde dahi UÇÖ'nün, günümüzde ve yakın gelecekte önemli bir fonksiyon üstlenebilmesinin yolu açılmaktadır.

Çalışmada tarihsel süreç içerisinde incelendiği üzere 1919'dan beri konjonktürel gelişmelere uygun hareket ederek yeni politikalar, standartlar, kavramlar ve dokümanlar üretmeyi başaran UÇÖ, yeni dönemde yaşanan 
değişimlerin farkındalığıyla, 21 Haziran 2019'da işin geleceğine yönelik Çalışma Yaşamının Geleceği Yüzüncü Y1l Bildirgesi’ni kabul etmiştir. Bildirgede UÇÖ, küresel sosyal adalete ilişkin anayasal görevini insan odaklı yaklaşım temelinde ileriye taşıyacağını ilan etmiş; sürdürülebilir kalkınmanın anahtarı olarak uygun iş ile çok taraflı katılım ve işbirliğinin önemini bir kez daha vurgulamıştır. Bu çerçevede teknolojik ilerlemeden tam olarak yararlanılması, eğitim sisteminin işgücü piyasasının ihtiyaçlarına göre şekillenmesi, aktif yaşlanmaya yönelik tedbirlerin alınması ve sosyal koruma sistemlerinin gelişmelere uyarlanması, kamu ve özel sektörün büyüme ve istihdam yaratmadaki rolünün desteklenmesi ile uluslararası işgücü göçünün düzenlenmesi hedeflenmiştir. Bu hedefler; makroekonomik, ticaret, sanayi, alt yapı ve stratejik sektörel yatırımları yönlendirecek, işin dijital dönüşümünde karşılaşılacak zorluk ve firsatlara cevap verecek politikalar gerektirmektedir (ILO, 21 June 2019, s. 1-8).

İşin sosyal adaleti sağlamada ne kadar hayati olduğu fikri, tam istihdam ve yaşam standartlarını uygun işlerle yükseltme hedefi; gelecekte de UÇÖ’nün pusulası olmaya devam edecektir. Sosyal içerilmenin ön koşulu olan iş, maddi ihtiyaçların yanı sıra kendini gerçekleştirme ve kişisel gelişim ihtiyacına da cevap vermeli, birey için bir amaç ve anlam taşımalı, toplumsal bölünmüşlükleri azaltmalıdır (ILO, 2015, s. 9-10). Bu bağlamda küresel ve toplumsal geleceğimizi yakından ilgilendiren işin geleceğini önemli derecede etkileyecek unsurlar; teknolojik dönüşüm ve işin dijitalizasyonu, dünyanın farklı bölgelerinde farklı bir seyir takip eden demografik eğilimler, işgücünün kompozisyonunda, organizasyonunda ve düzenlenmesindeki değişimler ile işgücü göçünün çalışma yaşamı üzerine karşılıklı etkileridir (ILO, 2017, s. 3-9).

$\mathrm{Bu}$ unsurlardan teknolojinin gelecekte insanları özellikle ağır, tehlikeli ve kirli işlerden kurtaracağı, olası kaza ve yaralanmaların önüne geçeceği; buna karşın insanın iş üzerindeki hâkimiyetini ve iş tatminini azaltacağ yönündeki tartışmalar uzunca bir süredir devam etmektedir. Ancak veriler teknolojinin uzun dönemde yok ettiği işten daha fazlasını yaratarak hayat standartlarını yükselttiğini kanıtlamaktadır. Günümüzde teknolojinin emeği beklendiği kadar ikame edip edemediği, yeterince uygun iş yaratıp yaratamadığı tartışılmakta ancak teknolojik gelişmelerin kaçınılmazlığı kabul görmektedir. Gelecekte yeni teknolojilerin iş yaşamında yaratacağı dönüşümlerin ve sağlayacağ1 nimetlerin küresel eşitsizlikleri artırmayacak yönde yönetimi daha da önem kazanmaktadır (ILO, 29-30 September 2017, s.4). 
Yeni ve iyi işlere olan ihtiyacın (projeksiyonlara göre 2030'da 600 milyon yeni işe ihtiyaç vardır); bir diğer unsur olan demografik eğilimlerin de etkisiyle bakım hizmetleri ve yeşil işlerle karşılanma olasılığı yüksektir, ancak küreselleşen üretim bir yandan yeni firsatlar yaratırken bir yandan da artan rekabetin etkisiyle çalışma haklarının aşağıya çekilmesi riskini barındırmaktadır. İş aramak için göç eden insanlar küresel düzeyde yeni sorunlara yol açarken, işgücü piyasası kurumları ulusal düzeyde şekillenmeye devam etmektedir (ILO, 2015, s. 1-7).

İşücünün kompozisyonu açısından bakıldığında, başlangıçtan beri organize etmesi daha kolay olduğundan UÇÖ’nün daha çok referans aldığ 1 düzenli, tam zamanlı, ücretli, öncelikli olarak aile reisi erkeğin çalıştı̆̆ iş kalıplarının günümüzde yerini daha geniş, parçalı ve farklılaşmış kalıplara bıraktığ 1 görülmektedir. Toplu pazarlık sistemi adem-i merkeziyetçiliğe doğru evrilmiş; bazı sektörlerde ise tamamen kaybolmuştur (Vaughan-Whitehead ve VazquzeAlvarez, 2018, s. 52-55). Düzenli iş sözleşmeleriyle çalışarak tek bir işten emekli olmanın giderek zorlaştığı günümüzde istikrarlı işlerin mekansal olarak değişken, küçük birimlerce yerine getirilen, esnek ve kısa dönemli işlerle ne boyutta ikame edileceği tartışılmaktadır. Yeni iş ilişkilerinin güvensiz ve izole olma ihtimalinin yanı sıra yetenekli bireylere beklenmedik firsatlar yaratması, içeriğinin zenginleşmesi ve bireyin iş üzerindeki kontrolünün artması da olasıdır. Ücretli kesimin işgücündeki oranının artmaması enformelden formel işlere tek yönlü geçişte tıkanma olduğunu göstermekte, kendi başına çalışma yeni bir alternatif olarak belirmektedir. İşe yüksek oranda dâhil olmak, çalışanla birlikte işletmenin de performansını artıracağından, teknoloji çağında çalışanların çalışırken daha fazla evde olabilecekleri bir değişim süreci tercih edilebilir. İşle toplum ilişkisini uyumlaştırmada kolektif mekanizmalar yerine bireysel girişim ve sorumluluk ön plana çıkmaktadır (ILO, 2015, s. 10, 14).

Bu bağlamda beceriler ve eğitim geleceğin iş gündeminin kilit kavramları olmaya devam edecek, eğitim sistemiyle iş dünyası arasındaki bağlantıyı güçlendirmek daha önemli hale gelecektir. Sosyal dışlanma kişilerin iş dünyasına kabulünü sağlayan esnek becerileri kazanmasını engellediğinden, bu riskle karşı karşıya bulunan dezavantajlı kesimler için daha kapsamlı ve hedefli politikalara ihtiyaç vardır. Küresel ekonominin makroekonomik yönetiminde güçlü bir büyüme sağlandıkça uygun iş amacı da ilerlemeye devam edecektir (ILO, 29-30 September 2017, s. 3, 8). 
Diğer yandan devlet, ulusal, bölgesel ve küresel düzeyde düzenleyici çerçeveyi çizmekte, kamu sektöründe işveren olmaya devam etmekte, ancak yeni işlerin büyük kısmı özel sektörde yaratılmakta ve işin organizasyonunun asıl etkileri burada ortaya çıkmaktadır. Bu nedenle birim olarak işletme işin geleceğinde belirleyici bir dinamik olacaktır. Bu çerçevede günümüzde işletme davranışını etkileyen temel etmenlerden olan sosyal sorumluluk kuralları işin geleceğinde de önemli bir yer tutacaktır. Bu kurallar kamuoyu nezdinde saygınlık kazanmak için zamanla sertleşmiş, uluslararası toplumun işletmelerden bu kuralları yerine getirmeleri yönündeki beklentisi artmıştır (ILO, 2015, s. 13, 16).

Günümüzde değişen küresel üretim organizasyonunun yönetimi ise ulusal ve uluslararası düzeyde kanunlar, işgücü piyasası kurumları, devlet-işçi-işveren örgütlerinin etkileşimi, anlaşma ve sözleşmeler gibi araçlarla sağlanmaktadır. UÇÖ uluslararası düzeyde bu araçların yönetiminde, uluslararası sözleşmelerin hayata geçirilmesi noktasında temel bir rol oynamaktadır. Bu düzenlemelerin kapsamı ve etkinliği üzerine fikir alışverişleri devam etmekte; artan kuralsızlaştırma eğilimine karşın çalışma standartları bölgesel entegrasyonların kilit bileşenleri arasına girmekte ve ticaret anlaşmalarına entegre edilmektedir (ILO, 2015, s. 15-16).

Küreselleşmeyi yapılandırma sürecinde işin geleceğine dair tartışmalar ana hatlarıyla bu çerçevede devam ederken, bu tartışmalarla da bağlantılı olarak ÜÇO gündemindeki öncelikli konulardan ilki çalışma mevzuatından iş sözleşmelerine ve denetim sistemine kadar tüm kurumsal yapının yeniden ele alınmasıdır. Bu kapsamda öncelikle UÇÖ’nün 2019 yılında yayımlanan Çalışma Yaşamının Geleceği Küresel Komisyonu Raporu'nda da yer verilen, tüm çalışanlar için temel çalışma haklarına saygılı, insanca yaşamaya yetecek bir geliri içeren, iş saatleri üzerindeki bireysel egemenliğin arttığı, evrensel bir iş garantisi sisteminin hayata geçirilmesi için uğraş verilmelidir. Buna, enformel kesimden dijital iş platformlarındakilere kadar çalışanların mümkün olan en geniş kesimini kapsayan, teknolojiden de faydalanan bir sosyal diyaloğun kamu politikalarınca garantiye alınması çabası da eşlik etmelidir. (ILO, 2019a, s. 12-14). Bu süreçte, hem fiziksel hem de dijital ortamlardaki sürdürülebilir ve uygun işler, öncelikli yatırım alanları olmalıdır. Ticari, finansal, ekonomik ve sosyal politikalar arasındaki güçlü bağlar; bu alanlarda politika üreten uluslararası kuruluşların uygun iş gündeminde ortak çalışmalar yürütmesini gerektirmektedir. 
Diğer öncelikli konu, sosyal huzursuzlukların ve enformelliğin kol gezdiği günümüz dünyasında, süreci tersine çevirebilecek bölüştürücü işlevi olan sağlam işgücü piyasası kurumları ve politikalarının tesisidir (Marshall ve Fenwick, 2016, s. 3-4, 9). Serbest rekabet, kazanan ve kaybedenlerden oluşan farklı sosyal gruplar doğurmakta; sistemin sürdürülebilirliği için işgücünün hareketliliğini ve profesyonel becerilerini artıracak aktif işgücü piyasası politikaları ile sosyal şokları azaltacak ekonomi politikalarına ihtiyaç duyulmaktadır. Burada UÇÖ’ye düşen temel görev güçlü sosyal politikalar oluşturmada teknik yardım ve destek sunmanın yanı sıra ülkelerin bu yöndeki farkındalığını artırmaktır (Onida, 2008, s. 23). Örneğin, uluslararası ticaret anlaşmalarında gittikçe daha fazla oranda sosyal hükme yer verilmesi, hem UÇÖ’nün amaçlarının uluslararası farkındalığının yükselmesine hem de kurmaya çalıştı̆̆ standartlar sisteminin güçlenmesine ve teknik yardımlarının artmasına neden olabilecek bir faktördür (Ebert ve Posthuma, 2011, s. 1-3).

Bölüştürücü politikalar bağlamında, örneğin 2008 krizi sonrasında UÇÖ’nün küresel düzeyde önerdiği, yetersiz düzeyde kalan talebi canlandırıcı, finansal piyasaları istikrara kavuşturucu, gelir dağılımı bozukluklarını giderici politikalar; uluslararası Keynesçi politika önerileri ile de paralellik arz etmektedir. Finansal sektörün reel sektöre ve sosyal gelişmeye katkı sunmasının uluslararası politikaların uyumlaştırılmasıyla mümkün olacağını savunan UÇÖ bu politikaları, uzun vadede kitlesel işsizliğe ve yoksulluğa çare olarak gündeme getirmiştir. Böylece kriz sonrasında içe dönük, korumacı politikalar yerine stratejik sektörlerin desteklenerek, piyasalardaki tıkanıkların giderilmesi, büyük çaplı yatırımlara öncelik verilmesi, daha derinlerdeki sosyal eşitsizliklerin kamusal müdahalelerle azaltılması ile düşük ve orta gelirli ülkelerin çıkarlarının da dikkate alınması hedeflenmiştir (ILO, 2009, s. v-xv). Uluslararası düzlemde de tartışılmakta olan bu politikaların sürekli gündemde tutularak eşgüdümünün sağlanmasında UÇÖ’nün daha aktif bir rol üstlenmesi beklenmektedir.

Bir başka öncelikli alan uygun teşvik mekanizmasının tesisidir. Tarihi gelişmelerin ortaya koyduğu tecrübe neticesinde olumlu uygulama ve ödüllendirmelerin olumsuz uygulama ve cezalandırmalara kıyasla daha iyi sonuç verdiği düşüncesinden hareketle, UÇÖ tercihli ticaretin, karşılıksız yardımların ya da borçların, hak ihlallerinin ortadan kaldırılması ya da sosyal diyaloğun artırılması şartına bağlanması gibi olumlu teşvikleri çok uluslu platformlarda dile getirmektedir. UÇÖ, çalışma standartlarını gözleme ve 
denetleme görevini titizlikle yerine getirirken, uluslararası kuruluşlarla ve sosyal taraflarla işbirliği içerisinde olmalı, yönetiminde yer aldığı programlara yerel ve merkezi hükümetlerden finansal ve kurumsal destek alma yolunda girişimlerde bulunmalıdır (Onida, 2008, s. 23-24).

Diğer yandan, içinde bulunduğumuz yüzyılda küreselleşmenin yarattığ1 sorunlar karşısında; işçi ve işveren kesimi arasında daha dengeli bir ilişki temin etmek üzere, geleneksel birleşenlerinden sendikaların tekrar belirli bir güce ulaştırılması ve anayasal sorumluluğu doğrultusunda toplu pazarlık sisteminin canlandırılması UÇÖ’nün gündemindeki bir başka konudur. Sendikaların en önemli araçlarından olan toplu pazarlık sistemi; üretim ilişkilerini yeniden yapılandırarak, iş ilişkisine istikrar, adalet ve insani değerler katmakta ve kapitalizmi dengelemektedir (Kaufman, 2010, s. 76). Özellikle çok uluslu şirketlerin taraf olacağı toplu sözleşmeler yoluyla temel çalışma hakları bu şirketlerin faaliyet gösterdiği ülkelerde güvence altına alınabilir. Ulusal çalışma mevzuatının yetersiz ve sendikalaşma oranlarının düşük olduğu ülkelerde uluslararası çerçeve sözleşmeleri; çalışma haklarının güvence altına alınmasını kolaylaştırabilir. Halihazırda imzalanan uluslararası çerçeve sözleşmelerinin ortak özelliği çalışma haklarının korunmasına odaklanmalarıdır (Telljohann vd., 22 June 2009, s. 6-7).

Diğer yandan, çok uluslu şirketlerde sivil toplumun da katkısıyla UÇÖ standartları doğrultusunda oluşturulacak kurumsal sosyal sorumluluk kuralları, bu şirketlerin tüm dünyadaki tedarikçileri için de geçerli olabileceği gibi tüketicilerin bilinçli taleplerinin de bu yönde yoğunlaşmasını sağlayabilir. Küresel eğilim; uluslararası çalışma standartlarının, artan şekilde işletme politikalarına dâhil edilmesi yönündedir. Uluslararası çalışma standartları, 1998 tarihli UÇÖ Bildirgesi sonrasında, BM ve OECD gibi kuruluşların yayımladıkları rehber ilkelerde, ISO 26000 standart ilkelerinde de referans alınmaya başlanmıştır. Bunlar arasında öne çıkan BM Küresel İlkeler Sözleşmesi, işletmeler ve sivil toplum öğeleri için politika platformu oluşturarak; insan, çalışma ve çevre hakları ile yolsuzlukla mücadele alanlarında belirlenmiş temel ilkeler çerçevesinde küresel ekonominin insani yüzünü güçlendirmeye çalışan en büyük gönüllü kurumsal sosyal sorumluluk girişimi olma özelliğini korumaktadır. Bu ilkelerden çalışma haklarına ilişkin olanlar, 1998 tarihli UÇÖ Sözleşmesi temellidir (The Global Voice of Business, May 2015, s. 4, 7-8, 12-13). UÇÖ bu gibi çalışma haklarına saygılı uygulamaların denetimini yapıp onları teşvik edebilir, olumlu 
örnekleri tüm dünyaya ilan ederek uygulamaların cazibesini artırabilir. $\mathrm{Bu}$ bağlamda, yeni teknolojiler de UÇÖ’ye çalışma koşullarının etkin denetiminde, toplanan bilgilerin işlenişinde yardımcı olacak şekilde kullanılabilir (ILO, 2019a, s. 55).

Ortaya konulduğu üzere, küreselleşen dünyanın rekabetçi ve entegre yapısı içerisinde, çalışma koşullarının iyileştirilmesinde, daha adil ve güçlü bir ekonomik yapı oluşturulmasında, devletler ve diğer paydaşların yanı sıra UÇÖ’ye çok önemli görevler düşmektedir. Dünya ölçeğinde çalışma koşullarını iyileştirici, istihdamı artırıcı ve eşitsizlikleri giderici politikaların hayata geçirilmesinde UÇÖ’nün sergileyeceği performans, dünya ekonomisinde bir asırdır varlığını sürdüren bu kurumun gelecekteki etkinliğini de tayin edecektir.

\section{Sonuç}

Yüz yıllık tarihinde dünyayı derinden etkileyen önemli demografik, ideolojik, sosyal ve ekonomik dönüşümlere şahit olan UÇÖ, sosyal adalet ve çalışma hakları ile ilgili tartışmalarda sürekli merkezi bir yer işgal etmiştir. Bu konumuyla UÇÖ, dünya ekonomisi ve çalışma hayatında yaşanan değişimlere karşı uygun politika ve argümanlar geliştirmeyi her seferinde başarmıştır. Bu süreçte UÇÖ’nün etkinliği ise devletin piyasa karşısındaki gücüne ve içinde bulunulan konjonktürel evreye bağlı olarak şekillenmiştir.

Milenyum sonrası dönemde hayat standartları yükselmiş ancak işsizlik, yoksulluk ve eşitsizlikler önlenememiştir. UÇÖ değişen şartlarla birlikte bakış açısını değiştirmiş; faaliyetlerinin odağını, yasal düzenlemelerden, esnek hukuk uygulamaları ile uygun iş gündeminde olduğu gibi çalışma haklarına saygı merkezli kavramlara kaydırmıştır. Diğer yandan, enformel sektörün de sesi olma çabasıyla sivil toplum başta olmak üzere ulusal ve uluslararası diğer aktör ve kuruluşlarla işbirliği içerisine girmiş, daima küresel karar alma süreçlerindeki meşruiyetini ve çalışma standartlarına saygıyı artırmayı hedeflemiştir. Bu bağlamda UÇÖ, G20 başta olmak üzere günümüzün başat uluslararası platformlarında çalışma yaşamına ilişkin farkındalığı artıracak paylaşımlarda bulunmakta, verdiği teknik yardımlarla çalışma haklarının iyileşmesine katkı sunmaktadir.

İstihdam ve üretim kalıplarındaki değişimler, demografik ve teknolojik dönüşümler ile önlenemeyen eşitsizlikler işin geleceğini, dolayısıyla da toplumsal 
geleceğimizi etkilemektedir. Bu bağlamda çalışan haklarına saygılı küresel bir iş çerçevesi oluşturulmasında, UÇÖ’ye olan ihtiyaç her zamankinden fazladır. Artan uygun iş taleplerine cevap vermek ve herhangi bir sosyal güvencesi olmayan hali hazırda dünya nüfusunun yarısından fazlasını oluşturan güvencesiz kesime koruma sağlamak başta olmak üzere sosyal sorunlara sürdürülebilir çözümler üretmek gerekmektedir. Artan eşitsizlikler; ekonomik sıkıntıların adil olarak paylaşıldığına olan toplumsal inancı sarsarak, sosyal bütünlük ve istikrara zarar vermekte, devletlerin ve uluslararası kuruluşların çözüm üretmesini zorlaştırmaktadır.

Bu noktada üretimin gittikçe uluslararasılaşarak karmaşıklaştığı günümüzde; sınırları aşarak, UÇÖ’de temsil olanağı bulamamış diğer tüm unsurları da kapsayan, bütünleştirici bir küresel sosyal diyalog; önemli bir çözüm önerisi olarak belirmektedir. Geleneksel üçlü yapıda temsil edilmeyen kırsal kesim başta olmak üzere enformel olarak çalışan dezavantajlı kesimlerin sürece dâhil edilmesi, hem UÇÖ’nün klasik yapısının günümüz koşullarına uygunluğuna yönelik eleştirileri dikkate almak, hem de UÇÖ'nün temsil meşruiyetini artırıcı, tamamlayıcı bir unsur olarak sağlayacağ kazançlar açısından önemlidir. Hak ve özgürlükler günümüzde bireysel yoldan ve klasik kurumsal yapılardan ziyade teknolojik ağlar üzerinden dile getirilmekte; daha üst yapıda ise çok taraflı girişimlere alternatif olarak ikili ya da bölgesel işbirlikleri tercih edilmektedir. Bu çerçevede, UÇÖ'nün çalışma standartlarını doğrudan referans alan kurumsal sosyal sorumluluk girişimlerinde daha aktif bir rol üstlenmesi ona önemli bir açılım sağlayabilir.

Çalışma Yaşamının Geleceği Yüzüncü Yıl Bildirgesi’nde ve diğer UÇÖ düzenlemelerinde ifadesini bulan sosyal adalet, çalışma haklarına saygı, insan onuruna uygun bir iş ve gelir, sosyal koruma; işin geleceğini insan odaklı olarak şekillendirecek ve UÇÖ’yü sonraki yüzyıla taşıyacak önemde amaçlardır ve uygun yol haritalarını da içlerinde barındırmaktadır. Bu yolda ilerlemek; insanı ve işi merkeze alan sosyal sözleşmeyi yeniden canlandırarak, ulusal ve uluslararası tüm aktörleri onun etrafında kenetlemekle mümkündür. Bunun için ise insanı sosyal risklere karşı koruyacak sosyal politikaları uluslararası düzeyde yaygınlaştırmak gerekmektedir.

Finansal Destek: Yazar bu çalışma için finansal destek almamışlardır. 


\section{Kaynakça/References}

Charnovitz, S. (2000). The International Labour Organization in its Second Century. Von Bogdandy, A., Wolfrum, R. (Ed.), Max Planck Yearbook of United Nations Law (ss. 147-184). Heidelberg: Max Planc Institute.

Coxson, C. R. (1999). The 1998 ILO Declaration on Fundamental Principles and Rights at Work: Promoting Labor Law Reforms Through the ILO as an Alternative to Imposing Coercive Trade Sanctions. Penn State International Law Review, 17(3), 469-504.

Delican, M. (2017). Uluslararasılaşma ve küreselleşme bağlamında karşılaştırmalı endüstri ilişkileri: gelişmeler ve teorik yaklaşımlar. Sosyal Siyaset Konferansları Dergisi, 72, 1-33.

Ebert, F. C., \& Posthuma, A. (2011). Labour Provisions in trade arrangements: current trends and perspectives. (International Labour Organization International Institute for Labour Studies Disscussion Paper Series No. 205) Geneva: ILO.

Global Deal. (2018). Building Trust in a Changing World of Work: The Global Deal for Decent Work and Inclusive Growth Flagship Report 2018. Geneva: ILO, Paris: OECD Publishing.

Gravel, E., Kohiyama T., \& Tsotroudi K. (2014) A legal perspective on the role of international labour standards in rebalancing globalization. Revue Interventions économiques, Papers in Political Economy, 49, 1-20.

Hansenne, M. (1994). Promoting Social Justice in the new global economy. Monthly Labor Review, 3-4.

Igwe, I. O. C. (April 2018). History of the international economy: the bretton woods system and its impact on the economic development of developing countries. Athens Journal of Law, 4(2), 105-126.

ILO. (1919), Constitution of the International Labour Organization, Erişim Tarihi: 15 Ekim 2019, https://www.ilo.org/dyn/normlex/en/f?p=1000:62:0::NO:62:P62_LIST_ ENTRIE_ID:2453907:NO

ILO. (10 May 1944), Declaration Concerning the Aims and Purposes of the International Labour Organization (Declaration of Philadelphia). Geneva: ILO.

ILO. (1995). World Employment 1995: An ILO Report. Geneva: ILO.

ILO. (1996). World Employment Report 1996/97: National Policies in a Global Context. Geneva: ILO.

ILO. (June 1999). Report of the Director-General: Decent Work, International Labour Office 87th Session. Geneva: ILO.

ILO. (18 June 1998). ILO Declaration on Fundamental Principles and Rights at Work and Its Follow-Up: Adopted by the International Labour Conference at its Eighty-sixth Session. Geneva: ILO.

ILO. (22 March 1999). Statement by Mr. Juan Somavia Director General of the International Labour Office Upon Taking his Oath of Office, Erişim Tarihi: 15 Ekim 2019, https://www.ilo.org/public/english/bureau/dgo/speeches/somavia/1999/oath.htm. 
ILO. (01 December 1999). ILO Calls For New Multilateral Initiative to Address Social Implications of Globalization, Erişim Tarihi: 15 Ekim 2019, https:/www.ilo.org/ global/about-the-ilo/newsroom/news/WCMS_007962/lang--en/index.htm.

ILO. (March 2000). Report of the Working Party on the Social Dimensions of the Liberalization of International Trade, ILO Governing Body, 277th Session, GB.277/16. Geneva: ILO.

ILO. (November 2000). Framework for studies on integrated policies to achieve a wider sharing of the benefits of globalization, ILO Governing Body, 279th Session, GB.279/ $W P / S D G / 3$. Geneva: ILO.

ILO. (November 2001). Enhancing the action of the Working Party on the Social Dimension of Globalization: Next steps, ILO Governing Body, 282nd Session, GB.282/ WP/SDG/1. Geneva: ILO.

ILO. (2002). Decent Work and the Informal Economy, Report No VI, International Labour Conference 90th Session. Geneva: ILO.

ILO. (12 February 2008), The ILO at a Glance, Geneva: ILO.

ILO. (10 June 2008). ILO Declaration on Social Justice For A Fair Globalization, Adopted by International Labour Conference at its Ninety-seventh Session. Geneva: ILO.

ILO. (2009). The Financial and Economic Crisis: A Decent Work Response. Geneva: ILO.

ILO. (19 June 2009). Recovering from the Crisis: A Global Jobs Pact, Adopted by the International Labour Conference at its 98th Session. Geneva: ILO.

ILO. (2010). Review of the follow-up to the 1998 ILO Declaration on Fundamental Principles and Rights at Work, International Labour Conference 99th Session Seventh Item on the Agenda Report VII. Geneva: ILO.

ILO. (2012). Fundamental principles and rights at work: From commitment to action International Labour Conference 101st Session Sixth Item on Agenda Report VI. Geneva:ILO.

ILO. (2013). Report of the Director-General: Towards the ILO Centenary: Realities, renewal and tripartite commitment (Report 1(A), International Labour Conference, 102nd Session). Geneva: ILO.

ILO. (2015). Report of the Director-General: The Future of Work Centenary Initiative (Report 1, International Labour Conference, 104th Session). Geneva: ILO.

ILO. (2017). A Reflection on the Future of Work and Society. Geneva: ILO.

ILO. (29-30 September 2017). The ILO Global Commission for the Future of Work: Paper Presented at the G7 Labour and Employment Ministerial Meeting. Turin, Italy: ILO.

ILO. (2019a). Global Commission on the Future of Work: Work for a Brighter Future. Geneva: ILO.

ILO. (2019b). Conventions and Recommendations, Erişim Tarihi: 15 Ekim 2019, https://www.ilo.org/global/standards/introduction-to-international-labour-standards/ conventions-and-recommendations/lang--en/index.htm. 
ILO. (2019c). World Employment Social Outlook: Trends 2019. Geneva: ILO.

ILO. (21 June 2019). ILO Centenary Declaration For The Future of Work, Adopted by International Labour Conference at its One Hunderd Eighth Session. Geneva: ILO.

ILO, World Health Organization. (November 2009). Social Protection Floor Initiative: The Sixth Initiative of the CEB on the Global Financial and Economic Crisis and Its Impact on the Work of the UN System, Manual and Strategic Framework for Joint UN Country Operations. Geneva: ILO, WHO.

International Monetary and Financial Committee. (October 14, 2017). IMFC Statement by Guy Ryder Director General International Labour Organization,Thirty-Sixth Meeting. Washington D.C.: IMF.

International Trade Union Confederation. Constitution, Adopted at the Founding Congress, Vienne, November 2006, Amended by the Third Congress, Berlin, May 2014. Brussels: ITUC CSI IGB.

Jakovleski, V., Jerbi, S., Biersteker, T. (19 June 2019). The ILO's Role in Global Governance: Limits and Potential. Gironde, C., Garbonier, G. (Ed.), The ILO@100: Adressing the Past and Future of Work and Social Protection (ss. 82-108). Leiden, Boston: Brill Nijhoff Publishing.

Jansen, M., Lee, E. (2007). Trade and Employment: Challenges for Policy Research, A Joint Study of the Intrenational Labour Office and the Secretariat of the World Trade Organization. Geneva: World Trade Organization Secretariat.

Kaufman, B. E. (2010). The theoretical foundation of industrial relations and its implications for labour economics and human resource management. Industrial and Labor Relations Review, 64(1), 74-108.

Kott, S. (19 June 2019). ILO: Social Justice in a Global World? A History in Tension. Gironde, C., Garbonier, G. (Ed.), The ILO@100: Adressing the Past and Future of Work and Social Protection (ss. 21-39). Leiden, Boston: Brill Nijhoff Publishing.

Kunanayakam, T. (2013). The Declaration on the Right to Development in the Context of United Nations Standard Setting. United Nations Office of the High Commissioner for Human Rights (Ed.), Realizing the Right to Development: Essays in Commemoration of 25 Years of the United Nations Declaration on the Right to Development (ss. 17-48). New York and Geneva: United Nations Publications.

Langille, B. A. (2003-2004). Re-reading of the Preamble of the 1919 ILO Constitution in Light of Recent Data on FDI and Worker Rights. Columbia Journal of Transnational Law, 42(1), 87-99.

Lee, E. (1998). The Asian Financial Crisis: The Challenge for Social Policy. Geneva: ILO.

Marshall S., Fenwick C. (2016). Labour Law and Development: Characteristics and Challenges. Marshall S., Fenwick C. (Ed.), Labour Regulation and Development: Socio-Legal Perspectives (ss. 1-32). Cheltenham, UK, Northampton, MA, USA, ILO, Geneva, Switzerland: Edward Elgar Publishing. 
Morse, D. A. (1969). The Origin and Evolution of the I.L.O. and Its Role in the World Community. New York: Ithaca.

OECD. (1996). Trade, Employment and Labour Standards: A Study of Core Workers' Rights and International Trade. Paris: OECD Publishing.

O’Grady, J. (June 1994). Case2: Province of Ontario, Canada: Removing the Obstacles to Negotiated Adjustments. Sengenberger W., Campbell, D. (Ed.), Creating economic opportunities: The Role of Labour Standards in Industrial Restructuring (ss. 255-278). Geneva: ILO.

Onida, F. (July 2008). Labour Standards and ILO's Effectiveness in the Governance of Globalization (CESPRI Working Paper No. 218). Milano: CESPRI.

Perez, J. B. (2013). The International Labour Organization (ILO) as an Actor of Global Governance: Sufficiently Involved to Help Overcome the Latest Financial and Economic Crisis?, Yearbook on Humanitarian Action and Human Rights, Universidad de Deusto. ISSN: 1885 - 298X, 11/2013, Bilbao. 109-139.

Plata-Stenger V. (9 March 2016), Europe, the ILO and the Wider World (1919-1954), Erişim Tarihi: 15 Ekim 2019, http://ieg-ego.eu/en/threads/transnational-movementsand-organisations/international-organisations-and-congresses/veronique-platastenger-europe-the-ilo-and-the-wider-world-1919-1954.

Rodgers, G., Lee, E., Swepston, L., Van Daele, J. (2009). The International Labour Organization and the Quest for Social Justice, 1919-2009. Geneva: ILO.

Telljohann, V., da Costa, I., Müller, T., Rehfeldt, U. (June 2009). European and International Framework Agreements: Practical Experiences and Strategic Approaches (European Foundation for the Improvement of Living and Working Conditions EF/08/102). Luxembourg: Office for Official Publications of the European Communities.

The Global Voice of Business. (May 2015). Paper on International Labour Standards in the Contemporary Global Economy. London: The International Bar Association Global Employment Institute.

Thompson, E. P. (1966). The making of the English working class. New York: Vintage Books.

United Nations. (6-12 March 1995). Report of the world summit for social development. New York: UN.

United Nations. (8 September 2000). United Nations Millennium Declaration, Resolution Adopted by the General Assembly, A/RES/52/2, Fifty-fifth Session, Agenda Item 60 (b). New York: UN.

United Nations (16 September 2005) 2005 World Summit Outcome, Resolution Adopted by the General Assembly, A/RES/60/1, Sixtieth Session, Agenda Items 46 and 120. New York: UN.

United Nations. (24 October 2005). 2005 World Summit Outcome, Resolution Adopted by the General Assembly, Sixtieth Session, A/RES/60/1. New York: UN.

United Nations. (2006). Report of the Secretary-General on the Work of Organization, 
Sixty-first Session, Supplement No.1, A/61/1. New York: UN.

United Nations, (15 January 2008), Official List of Millennium Development Goals Indicators, Erişim Tarihi: 15 Ekim 2019, https://unstats.un.org/unsd/mdg/Host. aspx?Content=Indicators/OfficialList.htm.

Vaughan-Whitehead, D., Vazquze-Alvarez, R. (2018). Curbing Inequalities in Europe: The Impact of Industrial Relations and Labour Policies. Vaughan-Whitehead, D. (Ed.), Reducing Inequalities in Europe: How Industrial Relations and Labour Policies Can Close the Gap (ss. 1-67). Geneva, Switzerland: ILO, Cheltenham, UK, Northampton, MA, USA: Edward Elgar Publishing.

Viilup, E., Przetacznik, J. (January 2016). Briefing The International Labour Organisation and International Trade, European Parliament, Directorate-General for External Policies Policy Department, DG EXPO/B/PolDep/Note/2016_33. Brussels: European Parliament.

World Bank. (1990). World Development Report. Washington DC: World Bank.

World Commission on the Social Dimension of Globalization. (February 2004). A fair globalization: Creating opportunities for all. Geneva: ILO.

World Trade Organization. (18 December 1996). Singapore WTO Ministerial 1996: Ministerial Declaration, Erişim Tarihi: 15 Ekim 2019, https://www.wto.org/ english/thewto_e/minist_e/min96_e/wtodec_e.htm.

World Trade Organization, World Trade Report 2013: Factors Shaping the Future of the World Trade. Geneva: WTO. 